\title{
Diverse concepts of breeding for nitrogen use efficiency. A review
}

\author{
Edith T. Lammerts van Bueren ${ }^{1,2}$ • Paul C. Struik ${ }^{3}$
}

Accepted: 7 September 2017 / Published online: 3 October 2017

(C) The Author(s) 2017. This article is an open access publication

\begin{abstract}
Cropping systems require careful nitrogen (N) management to increase the sustainability of agricultural production. One important route towards enhanced sustainability is to increase nitrogen use efficiency. Improving nitrogen use efficiency encompasses increasing $\mathrm{N}$ uptake, $\mathrm{N}$ utilization efficiency, and $\mathrm{N}$ harvest index, each involving many crop physiological mechanisms and agronomic traits. Here, we review recent developments in cultural practices, cultivar choice, and breeding regarding nitrogen use efficiency. We add a comparative analysis of our own research on designing breeding strategies for nitrogen use efficiency in leafy and non-leafy vegetables, literature on breeding for nitrogen use efficiency in other vegetables (cabbage, cauliflower), and literature on breeding for nitrogen use efficiency in grain crops. We highlight traits that are generic across species, demonstrate how traits contributing to nitrogen use efficiency differ among crops, and show how cultural practice affects the relevance of these traits. Our review indicates that crops harvested in their early or late vegetative phase or reproductive phase differ in traits relevant to improve nitrogen use efficiency. Headforming crops (lettuce, cabbage) depend on the prolonged photosynthesis of outer leaves to provide the carbon sources for continued $\mathrm{N}$ supply and growth of the photosynthetically less active, younger inner leaves. Grain crops largely depend on prolonged $\mathrm{N}$ availability for uptake and on availability of $\mathrm{N}$
\end{abstract}

Edith T. Lammerts van Bueren

edith.lammertsvanbueren@wur.nl

1 Plant Breeding Wageningen UR, Wageningen University \& Research, Wageningen, The Netherlands

2 Louis Bolk Institute, Bunnik, The Netherlands

3 Centre for Crop Systems Analysis, Wageningen University \& Research, Wageningen, The Netherlands in stover for remobilization to the grains. Improving root performance is relevant for all crop types, but especially shortcycle vegetable crops benefit from early below-ground vigor. We conclude that there is sufficient genetic variation available among modern cultivars to further improve nitrogen use efficiency but that it requires integration of agronomy, crop physiology, and efficient selection strategies to make rapid progress in breeding. We also conclude that discriminative traits related to nitrogen use efficiency better express themselves under low input than under high input. However, testing under both low and high input can yield cultivars that are adapted to low-input conditions but also respond to high-input conditions. The benefits of increased nitrogen use efficiency through breeding are potentially large but realizing these benefits is challenged by the huge genotype-byenvironment interaction and the complex behavior of nitrogen in the cropping system.

Keywords Agronomic tool box · Breeding strategies . Nitrogen husbandry $\cdot$ Nutrient uptake $\cdot$ Root system $\cdot$ Selection criteria $\cdot$ Sustainable fertilizer use

\section{Contents}

1. Introduction

2. Conceptual framework and definitions

3. Objectives of the review

4. Recent developments in the agronomy of nitrogen use efficiency

5. Role of cultivar choice in nitrogen management

6. Crop duration in relation to nitrogen demand

7. Crop development in relation to $\mathrm{N}$ uptake and utilization: a crop physiological framework

8. Crop-specific traits related to nitrogen use efficiency: a breeding perspective for different crops 


\subsection{Spinach}

8.2 Lettuce

8.3 Cabbage

8.4 Potato

8.5 Wheat

8.6 Maize

8.7 Oilseed rape

9. Discussion

9.1 Do physiological differences among crop species lead to different traits contributing to nitrogen use efficiency?

9.1.1 Nitrogen uptake efficiency

9.1.2 Nitrogen utilization efficiency

9.1.3 Nitrogen uptake versus nitrogen utilization efficiency

9.2 Do crop traits contributing to nitrogen use efficiency differ for different management strategies?

9.3 Do crop species differ in their genetic variability and prospects to improve nitrogen use efficiency and related traits?

\section{Conclusions}

References

\section{Introduction}

Crops require large quantities of nitrogen $(\mathrm{N})$ to achieve high yields. This is illustrated in Fig. 1 in which the left panel shows a white cabbage crop with a low nitrogen supply and the right panel shows a cabbage crop of the same age grown under abundant $\mathrm{N}$ fertilization. Note the difference in leaf color and in green leaf area. Artificial $\mathrm{N}$ fertilization has increased food production significantly (Robertson and Vitousek 2009). Availability of $\mathrm{N}$ needs to be adjusted to the temporally dynamic need of the crop, but $\mathrm{N}$ also needs to be available in the space where crop roots can take it up and conditions are conducive for root activity and nutrient uptake. To some extent, this can be achieved by optimizing soil-plant interactions by avoiding soil compaction and allowing deep rooting to optimally explore large soil volumes for nutrient uptake. However, these interactions are complex, are affected by long-term soil processes, demonstrate a strong influence of weather conditions, and have a high degree of uncertainty (Tilman et al. 2002; Goulding et al. 2008).

Sustainable cropping systems require careful $\mathrm{N}$ management as $\mathrm{N}$ is usually very mobile. Inappropriate application (wrong quantity, timing, or positioning), alone or in combination with other forms of suboptimal agronomic practice (such as improper irrigation or poor disease control), can enhance risks of losses through immobilization, surface runoff, leaching through the soil profile, denitrification, or volatilization. Often, this may result in pollution of the environment (Erisman et al. 2008). Moreover, the production of mineral $\mathrm{N}$ fertilizer is very demanding in terms of fossil energy (Robertson and Vitousek 2009).

When considering improving $\mathrm{N}$ management, various sources of $\mathrm{N}$ for uptake by plants are to be taken into account: atmospheric deposition of nitrogenous compounds, soil $\mathrm{N}$, atmospheric $\mathrm{N}_{2}$ fixed by $\mathrm{N}$-fixing bacteria or algae, $\mathrm{N}$ mineralized from soil organic matter, nutrients $(\mathrm{N})$ through symbiosis of crop roots with beneficial soil micro-organisms, mineral $\mathrm{N}$ and $\mathrm{N}$ from organic inputs (such as animal manure, green manure), foliar nutrient application, nutrients in irrigation water (fertigation), etc. (Goulding et al. 2008).

Improving the efficiency of the use of nitrogen (NUE) is challenging. Seminal papers from 25 to 35 years ago demonstrated the increase in scientific insight in the agronomy of (De Wit 1992) and breeding for (Moll et al. 1982; Sattelmacher et al. 1994) NUE, but these have not prompted major efforts to breed for NUE as $\mathrm{N}$ was a relatively abundant and cheap resource. Where increases in NUE have been realized, such as in maize, this occurred through serendipity, associated with
Fig. 1 One cultivar of white cabbage, grown under different nitrogen regimes, during maturation. Left panel: low nitrogen availability $\left(150 \mathrm{~kg} \mathrm{~N} \mathrm{ha}^{-1}\right)$; right panel: high nitrogen availability (300 kg N ha ${ }^{-1}$ ). Picture: Y. Yi, Wageningen University \& Research
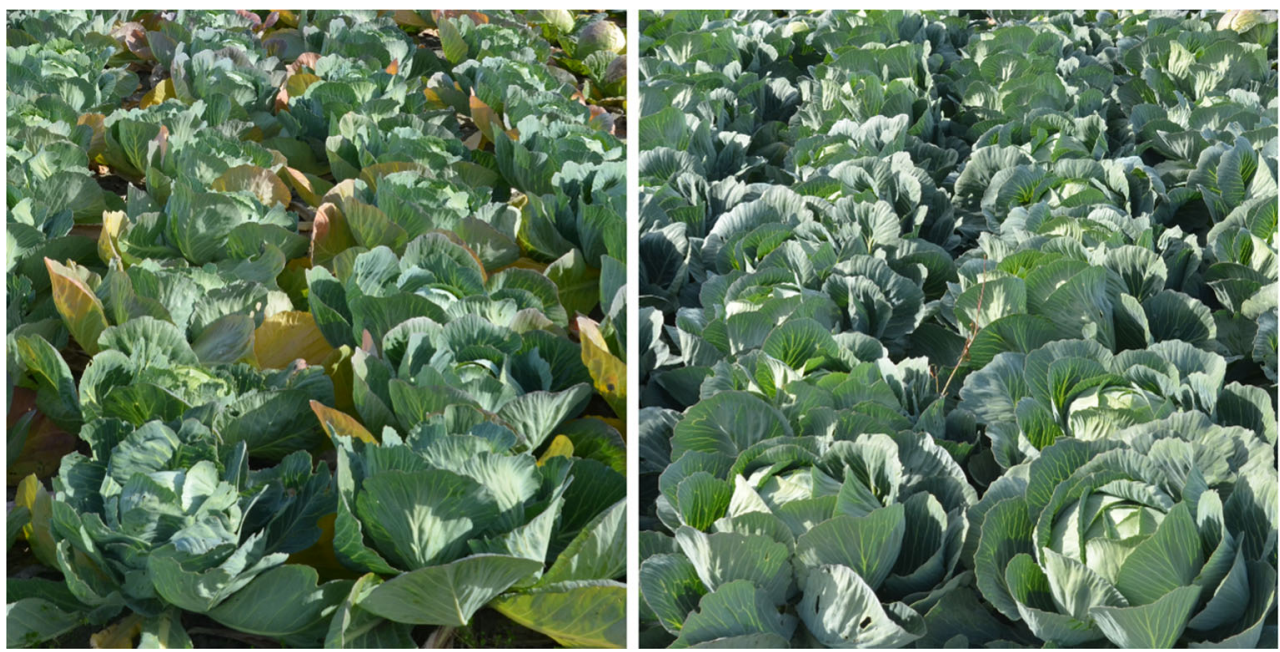
specific physiological mechanisms such as density tolerance in maize or increasing grain volume but with an associated decline in N grain concentration (Ciampitti and Vyn 2012). Nowadays, NUE is receiving increasingly more attention from both agronomy and breeding research as there is a greater sense of urgency for environmental care (Spiertz 2010; Swain et al. 2014; Han et al. 2015) and fertilizers are likely to become more expensive (Robertson and Vitousek 2009). However, breeding for NUE has not yet been incorporated to a large extent in practical breeding programs of many crops, because NUE is not only a complex trait but also one that is largely influenced by soil conditions that are difficult to measure or control.

Nitrogen use efficiency (NUE) comprises three key components: the nitrogen uptake efficiency $(\mathrm{NUpE})$, the nitrogen utilization efficiency (NUtE) in producing biomass, and the nitrogen harvest index (NHI) (Masclaux-Daubresse et al. 2010; Ciampitti and Vyn 2013). NUtE and NHI can be merged into one component: the utilization efficiency for harvestable products. Breeders can contribute to optimizing NUE of farming systems by producing cultivars with a high agronomic nitrogen use efficiency (AgNUE), i.e., cultivars that produce a large quantity of harvestable biomass per unit $\mathrm{N}$ supplied through fertilizer. For each component, many underlying physiological mechanisms and (combinations of) traits are relevant. These may include diverse and complex traits such as root architecture, the $\mathrm{N}$ uptake per unit of root length, leaf senescence and (re)mobilization of $\mathrm{N}$ in the plant, and $(\mathrm{N})$ harvest index (Malagoli et al. 2005; Barraclough et al. 2010; Gewin 2010). In the section below, we elaborate the conceptual framework of nitrogen use efficiency and provide the most important agronomic and physiological definitions related to this conceptual framework.

\section{Conceptual framework and definitions}

An elegant way to illustrate the various types of responses to nitrogen fertilizer is the so-called three-quadrant figure, which became popular in the scientific literature in the 1970s and 1980s. We use examples of wheat by Spiertz (1980) (as published by De Wit 1992) and of potato by Vos (2009). For examples of a diversity of other crops and conditions, please see Penning de Vries and van Keulen (1982), Van Keulen (1982), Baan Hofman (1988), Caihong and Chenliu (1989), De Wit (1992), and Hartemink et al. (2000). Note that the approach can also be used for other nutrients or for combinations of nutrients.

The three-quadrant diagram (see Figs. 2 and 3) is a useful tool to analyze the reasons why the response to nitrogen application (and therefore also the nitrogen use efficiency) varies among years, sites, cultivars, and crop management practices. The lower left quadrant is empty as both its axes are the same (the amount of nitrogen applied). The upper left panel

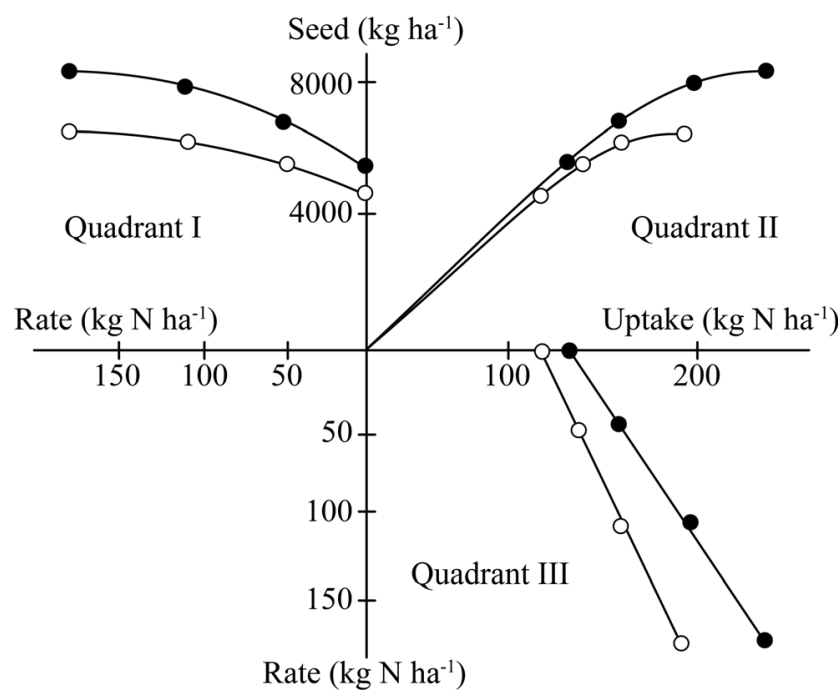

Fig. 2 Three-quadrant diagram of an experiment with different levels of artificial nitrogen fertilizer and with or without chemical control of ripening diseases in wheat. Open circles represent the data for $\mathrm{N}$ treatments without chemical disease control; closed circles represent the data for $\mathrm{N}$ treatments with chemical disease control. Based on Spiertz (1980) and De Wit (1992)

(Quadrant I) illustrates the agronomic response, i.e., the increase in yield with an increase in the amount of nitrogen supplied. This agronomic response is the resultant from two other responses: the response of the total amount of nitrogen taken up by the crop at maturity to nitrogen application (as illustrated in the lower right panel (Quadrant III)) and the response of the final yield to total nitrogen uptake at maturity

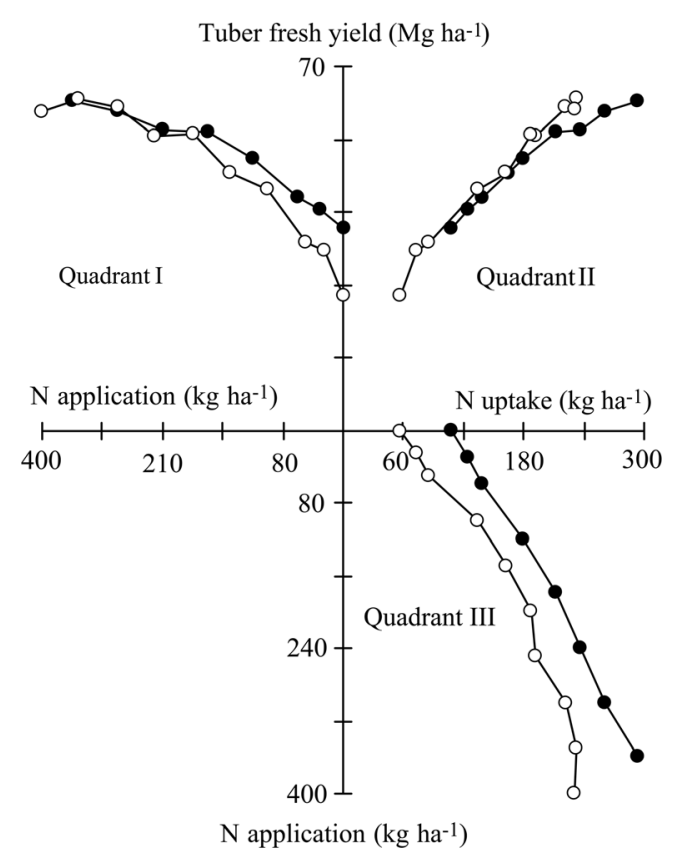

Fig. 3 Three-quadrant diagram of an experiment with different levels of artificial nitrogen fertilizer in potato carried out in two years. Different symbols reflect data from two different growing seasons. Based on Vos (2009) 
(as illustrated in the upper right panel (Quadrant II)). In fact, the slopes of the curves in Quadrant III reflect the change in nitrogen uptake efficiency with a change in nitrogen supply and the slopes of the curves in Quadrant II reflect the change in nitrogen utilization efficiency (the efficiency with which nitrogen taken up by the crop is converted into harvestable dry or fresh matter) with a change in total amount of nitrogen taken up at maturity. Quadrant III underlines the plant-soil interactions that cause variation in agronomic efficiency; the intercept in this quadrant is variable and associated with the amount of soil mineral nitrogen present before nitrogen application, the nitrogen mineralization during the growing season and the amount of nitrogen that becomes available from other sources, such as biological nitrogen fixation, atmospheric deposition, and runoff (Vos 2009). Quadrant II provides the crop physiological reasons for variation in agronomic nitrogen efficiency.

In the wheat example from Spiertz (1980), the agronomic efficiency of the nitrogen supplied (Quadrant I) in terms of grain yield is higher when diseases are controlled, especially at high $\mathrm{N}$ rate when the disease can be severe when not controlled (Fig. 2). Quadrant III shows that disease control resulted in more nitrogen taken up at the same nitrogen level compared with the situation without disease control. The difference in nitrogen uptake between with and without disease control increases with an increase in nitrogen supply, but even the intercept differs suggesting better uptake of nitrogen of other sources than the fertilizer supplied, such as nitrogen mineralized during the growing season, probably associated with higher longevity and activity of the canopy and thus the root system. Moreover, the crop can benefit better from the nitrogen taken up when also the nitrogen utilization efficiency is higher (Quadrant II) due to increased stay-green index and therefore better balance between sink and source (Sinclair and De Wit 1975; Van Keulen and Seligman 1987).

The potato example (Fig. 3) illustrates that the agronomic response can vary between years, even when the relationship between fresh tuber yield and nitrogen uptake is very similar. Quadrant I shows that the yields differ between the two years, but especially so in the lower ranges of nitrogen application. Quadrant III illustrates that these lower yields at low application rate are associated with lower uptake of nitrogen: apparently, there is less nitrogen available from other sources than the artificial fertilizer. The efficiency with which nitrogen taken up is converted into fresh tubers is similar, but the curve for the year with the lower uptake has moved to the left in Quadrant II compared to the curve for the year with the higher uptake.

Cereals, oilseed rape, leafy vegetables, and potato may differ in the patterns shown in these three-quadrant figures. It is likely that those differences are associated with differences in planting patterns and in root density, early in the growing season (see, e.g., Greenwood and Draycott 1988).
Based on the concepts described by the three-quadrant figures, we can define the following aspects and component traits of NUE:

- Biomass production per unit nitrogen available (Craswell and Godwin 1984), i.e., the agronomic nitrogen use efficiency based on total biomass;

- Harvestable biomass production (yield) per unit nitrogen supplied (Moll et al. 1982), often called agronomic nitrogen use efficiency (AgNUE) (Quadrant I);

- Nitrogen taken up per unit of nitrogen available in the soil, also called nitrogen uptake efficiency (NUpE) (Quadrant III);

- Biomass production per unit nitrogen taken up from the soil through absorption/acquisition and converted (utilized) through assimilation and remobilization (Moll et al. 1982), also called nitrogen utilization efficiency (NUtE) (Quadrant II);

- The ratio of harvested $\mathrm{N}$ to total crop $\mathrm{N}$, defined as the nitrogen harvest index (NHI);

- Nitrogen conversion efficiency for harvestable products, i.e., a combination of nitrogen utilization efficiency and nitrogen harvest index.

The most commonly used concepts are agronomic nitrogen use efficiency based on yield, nitrogen uptake efficiency, nitrogen utilization efficiency, and nitrogen harvest index.

\section{Objectives of the review}

To date much research on developing breeding strategies to improve NUE focuses on main crops including cereals, such as wheat and maize (e.g., Le Gouis et al. 2000; Dawson et al. 2011; Han et al. 2015) and oilseed crops such as canola and oilseed rape (e.g., Balint and Rengel 2008; Berry et al. 2010; Kessel et al. 2012). NUE of leafy vegetables such as spinach (Chan-Navarrete et al. 2014, 2016), lettuce (Kerbiriou et al. 2014, 2016), or cabbage (Schulte auf'm Erley et al. 2010) and NUE of non-leafy vegetable crops such as potato (Ospina et al. 2014) receive less attention.

In this review paper we will focus on the following questions:

1. Do physiological differences among crop species with respect to crop duration, (re)allocation processes of dry matter and $\mathrm{N}$ to harvestable products (leaves, heads, tubers, or grains), and growth types (maturity types) lead to different traits contributing to NUE?

2. Do crop traits for NUE differ for different management strategies?

3. Do crop species differ in their genetic variability and perspectives to improve NUE and related traits?

4. To what extent can knowledge on improving NUE of one crop species easily be translated to another crop species? 
To answer these questions, we describe recent developments in the agronomy of NUE and the role of cultivar choice and breeding in $\mathrm{N}$ management. We add our own research results for developing breeding strategies for NUE improvement in leafy vegetables (spinach (Spinacia oleracea L.) and lettuce (Lactuca sativa L.)) and a non-leafy vegetable (potato (Solanum tuberosum L.)) to compare such results with literature on breeding for NUE in cabbage (Brassica oleracea var. capitata L.) and grain crops (maize (Zea mays L.), oilseed rape (Brassica napus L.), and wheat (Triticum aestivum L.)).

\section{Recent developments in the agronomy of nitrogen use efficiency}

Agronomists can improve NUE both at an individual crop level and at a cropping system level. At the crop level, the aim is to improve $\mathrm{N}$ management through various complementary fertilization strategies and soil management regimes such as precision fertilization through split fertilizer strategies (Van Alphen and Stoorvogel 2000; Hirel et al. 2011) or fertilizer placement strategies (Burns et al. 2010). Modeling the $\mathrm{N}$ demand during crop growth is one of the tools to support precision fertilization to adjust application timing and placing of $\mathrm{N}$ based on measurements of plant material (such as petiole tests), measurements of soil conditions (available N), or both (Sibley et al. 2009, 2010; Schröder 2014), together with predictions of future gain in dry matter (De Koeijer et al. 1999).

At the cropping system level, the search is to design an optimal soil, crop (residue), and nutrient management system at the level of the entire rotation so that $\mathrm{N}$ is kept in the system and used and reused by various successive crops. Such strategies can include no-till systems, continuous cover cropping cultures, and preserving crop residues and soil organic matter, aiming at reducing excessive external input of $\mathrm{N}$, while maintaining an acceptable yield and sufficient profit margin for the farmers (e.g., Craswell and Lefroy 2001; Mirsky et al. 2012). Especially legumes can play an important role as cover crops as they are able to fix free atmospheric $\mathrm{N}_{2}$ and can thus lower the need for external $\mathrm{N}$ input in the growing system (ThorupKristensen 2006a). Recently, there is increasing attention for microbial ecology in the rhizosphere facilitating nutrient and water uptake (Philippot et al. 2013) and the role of belowground traits of crops such as root architecture and symbiosis with soil micro-organisms such as $\mathrm{N}$-fixing bacteria and mycorrhizas that support N uptake (Harrier 2001; Galván et al. 2011; Gewin 2010). To optimize crop rotation, knowledge on different rooting patterns of crops is crucial to alternate shallow-rooting crops (e.g., lettuce and onion that have most roots in the topsoil layer to a maximum of $0.4-0.6 \mathrm{~m}$ ) with deep-rooting crops (such as cabbage or wheat with a root depth up to $1.5-2.0 \mathrm{~m}$ depth) that can catch the leftover $\mathrm{N}$ that has leached to deep layers during cultivation of the shallow- rooting crops, depending on water movement through the soil profile during winter months and depth of groundwater (De Melo 2003; Thorup-Kristensen 2006a, b; Thorup-Kristensen et al. 2009; Hirel et al. 2011; Kerbiriou et al. 2016).

Such agronomic approaches to improve the NUE remain challenging as they require coping with variable and unpredictable environmental conditions (Tremblay and Bélec 2006) and are subject to strong genotype $\times$ environment interactions. Therefore, in the next sections, we will explore to what extent cultivars can play a role in supporting NUE in cropping systems.

\section{Role of cultivar choice in nitrogen management}

Cultivar choice is an important agronomic tool. Cultivars not only need to be adapted to such agronomic strategies supporting sustainable $\mathrm{N}$ management but also must allow such strategies to work optimally. This requires a knowledge-intensive and integrated approach. Neeteson and Wadman (1987) argued to focus on the economic optimum of nitrogen supply, i.e., the supply beyond which additional supply of nitrogen would cause an increase in production costs larger than the economic gain by additional yield. De Wit (1992) argued that the negative impact on the environment of intensive agriculture is associated with the law of diminishing returns meaning that the relationship between the amount of $\mathrm{N}$ supplied and the yield obtained is not linear but levels off (see also Figs. 2 and 3). However, this leveling off depends on the efficiency of the other resources at stake: farmers supply nitrogen up to a level at which also other resources are used optimally. De Wit indicated that no resource is used less efficiently and most resources are used more efficiently by a balanced increase in overall input. De Wit therefore called for search for the minimum of each production resource that is needed to allow maximum utilization of all other resources. This efficiency paradigm has large consequences for the general approach towards resource use efficiency:

- Under conditions with no $\mathrm{N}$ limitations (e.g., cheap $\mathrm{N}$ ), one would ask "how much $\mathrm{N}$ is needed to maximize economic crop yield for each genotype or to obtain maximum efficiency of other resources?", whereas

- Under limited N (e.g., low-input, organic agriculture), the question would rather be "which genotype can cope with low(er) $\mathrm{N}$ while maintaining a reasonably good yield and thus do more with less" (Good et al. 2004), i.e., reach maximum efficiency of the resource under consideration. Below, we review different crop types (leafy vegetables, non-leafy vegetables, and grain-producing crops) and their traits involved in NUE to provide general answers to these questions. 
6 Crop duration in relation to nitrogen demand

Crop species differ to a large extent in growth duration from sowing to harvest, ranging from, e.g., 21 days for baby leaf spinach to 270 days for winter wheat; but to what extent does that relate to $\mathrm{N}$ demand? Within crop species, such as potato, late-maturing cultivars have a longer crop growth and a longer period to invest in an extensive root system to take up more nitrogen to produce more biomass (Iwama 2008). However, between various crop species, shorter growth duration does not always seem to relate to a lower $\mathrm{N}$ demand: even shortcycle crops, such as spinach, may need high levels of $\mathrm{N}$ input to produce good yields in a short period of time; see Table 1 . In this table, we give an overview of different $\mathrm{N}$ management aspects of selected crop species with respect to crop growth cycle duration, average root depth, recommended $\mathrm{N}$ fertilization, average yield, and harvested $\mathrm{N}$.

Between grain crops such as spring and winter wheat, there are large differences in crop duration (varying from 170 to 270 days, respectively); winter wheat produces more biomass and grain yield than spring wheat and $\mathrm{N}$ demand for spring wheat is lower than that for winter wheat (Table 1). Winter wheat also has more time to develop an extensive root system and this deeper rooting ability $(1.6-2.0 \mathrm{~m})$ compared with spring wheat (approx. $1 \mathrm{~m}$ ), and therefore, capacity of winter wheat to better catch soil $\mathrm{N}$ that has leached to deeper layers leads to a higher NUE for winter wheat than that for spring wheat (Thorup-Kristensen et al. 2009).

With some cereal crops, there is a self-enforcing effect: extra $\mathrm{N}$ leads to more tillering and thus a greater demand for $\mathrm{N}$. But in a potato crop, extra $\mathrm{N}$ can also lead to more luxurious vegetative growth and delay of onset of tuber formation, and thus a larger $\mathrm{N}$ demand. The question of how more $\mathrm{N}$ availability will affect NUE will be addressed later in this paper.

As $\mathrm{N}$ demands differ among maturity types within a crop species but not always consistently among species, such as between leafy vegetables and seed-producing crops, we will explore more in depth the relationship between crop development, $\mathrm{N}$ uptake, and $\mathrm{N}$ utilization.

\section{Crop development in relation to $\mathbf{N}$ uptake and utilization: a crop physiological framework}

As summarized in general and for various crop species more specifically in Fig. 4, $\mathrm{N}$ is the main driver of plant growth and development and increases number of leaves and increases individual leaf area and total leaf area, number and length of internodes, and consequently plant height. $\mathrm{N}$ can also act as a growth regulator, for example split dressing of $\mathrm{N}$ can influence the number of grains/culm in cereals and the timing of the onset of tuber formation of potato or the number of branches (and therefore siliques) in oilseed rape. During early

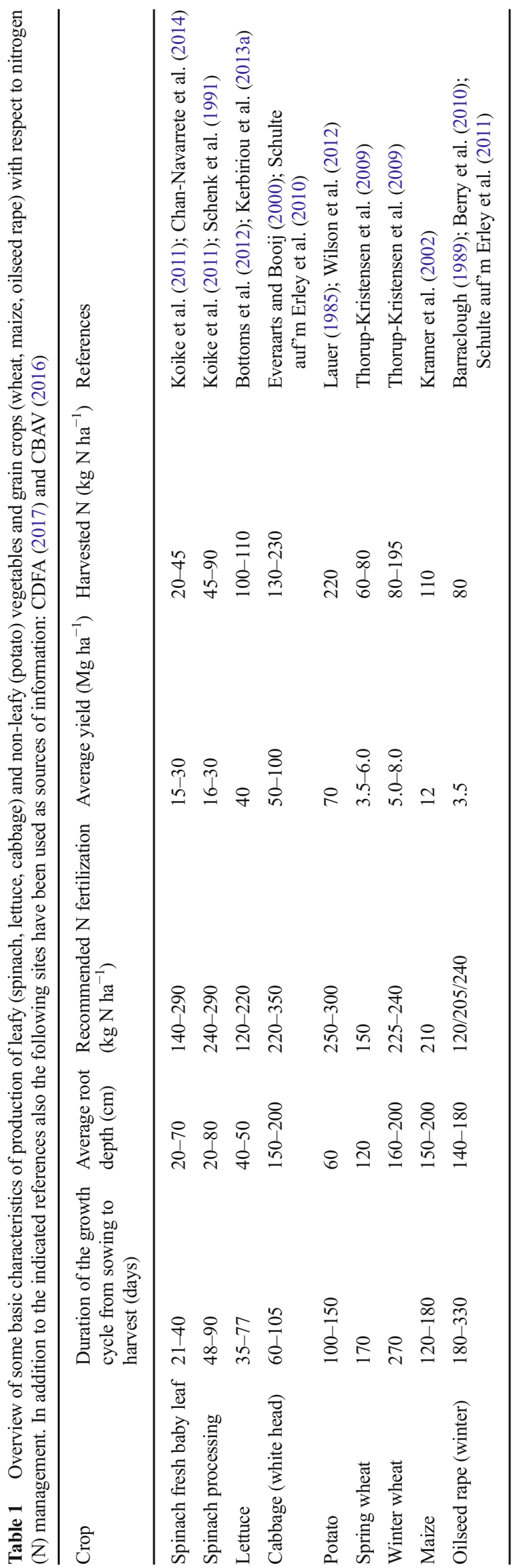




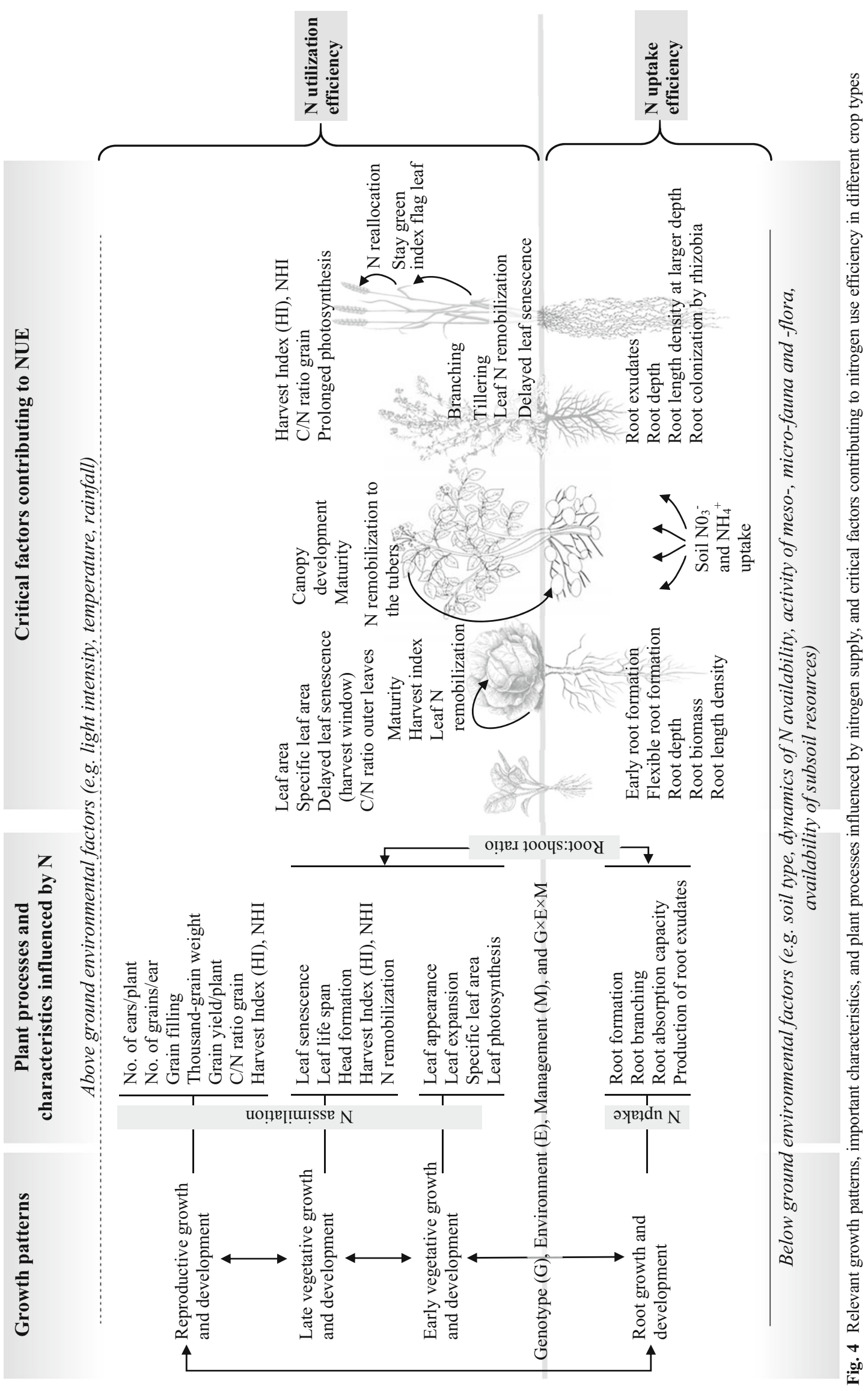


development, nitrogen is provided through uptake through roots and root development is dependent on assimilates transported from the lower leaves to the roots. When vegetative growth expands, $\mathrm{N}$ is often reallocated from older senescing leaves to the younger leaves. Also, for the reproductive organs (seeds), $\mathrm{N}$ is essential and is provided by either

i) Reallocation from senescing older leaves to the younger leaves and eventually to the reproductive organs or ii) Direct transport from the roots.

Root development is usually slowed down towards the end of the reproductive development. To facilitate continuous nutrient absorption, vegetative parts must remain photosynthetically active, which usually occurs in the younger leaves.

Nitrogen availability not only affects shoot growth but also $\mathrm{C}$ and $\mathrm{N}$ partitioning between roots and shoots. Root biomass and root depth at harvest vary between crop species; see Table 1. Robinson (1994) discusses that, in general, increased $\mathrm{N}$ supply decreases the root/shoot ratio but that the extent of the response differs between species and genotypes. Under low $\mathrm{N}$ supply, $\mathrm{N}$ uptake of a crop depends on soil mineral $\mathrm{N}$ availability and distribution, and root distribution over the soil profile, whereas under optimal or high $\mathrm{N}$ availability, $\mathrm{N}$ uptake depends more on the growth rate via $\mathrm{N}$ utilization processes (Gastal and Lemaire 2002).

Short-cycle, leafy vegetables such as lettuce and spinach produce biomass in a short time; they show high leaf appearance rate and leaf growth rate (Biemond 1995). They form a leaf rosette in their vegetative phase and are harvested before their reproductive state, and therefore, their phenology is often less complex. With such vegetables, the productive apparatus is also the targeted harvest product, so most $\mathrm{N}$ is required for leaf appearance, leaf expansion, and stay green. With leafy vegetables, it is not only the biomass production as such that is important. Producing high-quality and healthy produce (e.g., spinach requirements for dark leaves which demand a high $\mathrm{N}$ input) is equally relevant and that requires high $\mathrm{N}$ input as well. The total size of the leaf area per plant is important for the final yield and is determined by the rate and duration of leaf appearance and the rate and duration of expansion of individual leaves (Biemond 1995). The rate of leaf expansion and the area of the individual leaves increase with leaf rank up to a certain maximum before decreasing again. Both traits are influenced by $\mathrm{N}$ supply: more $\mathrm{N}$ leads to more rapid increase of leaf area. $\mathrm{N}$ also increases the specific leaf area (Biemond 1995) which is a measure for leaf thickness defined as the ratio of leaf area to leaf mass expressed in square centimeters per gram. Normally, the specific leaf area of an individual leaf does not change much during the life span of a leaf but the specific leaf area of the entire plant gradually decreases during vegetative growth as a result of the lower specific leaf area values for successive leaves (Biemond 1995). A higher specific leaf area means more light interception per unit dry matter invested in leaf production. Evans and Poorter (2001) found that increasing the specific leaf area was of greater importance for maximizing carbon gain per unit leaf mass than reallocating nitrogen between leaf pools.

The short crop duration of lettuce and spinach, especially fresh market baby leaf spinach with its high density of sowing (8.6-9.9 million seeds $\mathrm{ha}^{-1}$ ), only allows a short time for root development (resulting in shallow root depth, approximately 20-50 cm, see Table 1) (Chan-Navarrete et al. 2014; Kerbiriou et al. 2013a). Schenk et al. (1991) found that $80 \%$ of the total root length of spinach was in the upper $15 \mathrm{~cm}$. Biemond (1995) concluded from his experiments with spinach that for optimal growth and good green color, sufficient $\mathrm{N}$ must be present at the start of the crop growth because $\mathrm{N}$ shortage immediately results in smaller leaves. Split dressing is therefore not recommended. The whole spinach plant is harvested before flowering is initiated and before leaves start to senesce.

With lettuce, $70-80 \%$ of the $\mathrm{N}$ required is taken up between heading and harvest time (Bottoms et al. 2012). For lettuce, wrapper leaves and non-marketable heads may contain 10$40 \%$ of the above-ground $\mathrm{N}$ in the entire crop (Thompson and Doerge 1996; Hartz et al. 2000).

Cabbage is physiologically a special leafy crop as the younger leaves inside the head are not photosynthetically active. The outer leaves should remain active until harvest to stimulate $\mathrm{N}$ uptake. Also, the redistribution from older outer leaves to the young inner leaves forming the head is of importance (Schulte auf'm Erley et al. 2010). The head formation and thus the uptake and use of $\mathrm{N}$ in cabbage is more towards the second half of crop growth in a period during which one does not expect much increase in dry matter, due to unfavorable temperature and light conditions. Total dry matter production and head yields as well as plant $\mathrm{N}$ contents are strongly influenced by the level of $\mathrm{N}$ supply; number of leaves and harvest index were not found to be affected by $\mathrm{N}$ rate (Schulte auf'm Erley et al. 2010). Late types have a longer growing period and yield more than early and mid-early genotypes.

Cabbage roots very deep (up to $2 \mathrm{~m}$ for white cabbage) and is capable of depleting the soil at harvest to a large extent (Everaarts 1993; Thorup-Kristensen and Van den Boogaard 1998; Thorup-Kristensen and Nygaard Sørensen 1999; Everaarts and Booij 2000; Kristensen and ThorupKristensen 2004). Similar conclusions have been drawn for cauliflower (Brassica oleracea var. botrytis) which can root up to $1.15 \mathrm{~m}$ (Thorup-Kristensen and Van den Boogaard 1998; Rather et al. 2000). In an experiment with two cauliflower cultivars, two sites, and $\mathrm{N}$ levels, it was found that an increase in $\mathrm{N}$ supply led to increased root branching in the upper soil layers and decreased root branching in the subsoil layers (Thorup-Kristensen and Van den Boogaard 1998). 
Root and tuber crops, such as potato, have an intermediate position: vegetative growth and tuber growth partly overlap, although the dry matter and nutrient partitioning shifts gradually towards the tubers and some reallocation of nutrients from the haulm to the tubers does occur (Vos 1997). Vos (1999) estimated that 20 to $40 \%$ of the dry matter yield of potato is realized by reallocating nitrogen. In a well-fertilized potato crop, about $20-30 \%$ of the total $\mathrm{N}$ is found in the vine. Under excessive fertilizer application, over half of the total $\mathrm{N}$ may be in the vine, and under deficient fertilization, it can be as low as 10\% (Lauer 1985; Wilson et al. 2012). $\mathrm{N}$ affects both canopy (e.g., leaf appearance rate, leaf area index, branching) and tuber (e.g., dry matter yield, tuber size, and weight distributions) characteristics, but also $\mathrm{N}$ content and $\mathrm{N}$ uptake, although not tuber dry matter percentage (Vos 2009; Ospina et al. 2014). Vos (2009) stated that the potato plant has a specific response to nitrogen supply: it partitions its nitrogen supply in such a way that the productivity per unit of leaf area is much conserved. This also applies to the $\mathrm{N}$ concentration in the leaves and its change over the life span of the canopy. Variation in nitrogen supply mainly results in variation in total leaf area by adjustments in branching (i.e., leaf number) and individual leaf size. This strategy differs from the one found in other crop plants such as maize. Maize shows relatively little change in leaf area per plant with a change in nitrogen supply but the nitrogen concentration in the leaves strongly responds to nitrogen supply. Apparently, some crop plants prefer to dilute the available nitrogen while maintaining as much as possible the leaf area, thus maximizing light interception, whereas others reduce the leaf area without diluting the nitrogen, thus maximizing photosynthetic capacity per unit of leaf area.

With respect to uptake of $\mathrm{N}$ in potato, shoot biomass and tuber yield showed a positive correlation with root mass (Iwama 2008) and more specifically with total root surface and root length (Sattelmacher et al. 1990). Potato is not a deep-rooting crop compared to other field crops: on average, root depth is $60 \mathrm{~cm}$ although most roots are in the upper $30 \mathrm{~cm}$ (Iwama 2008).

Grain and seed crops (e.g., canola/oilseed rape, maize, rice, wheat) go through a transition from the vegetative to the reproductive stage to deliver the harvestable product. For wheat development, the timing of $\mathrm{N}$ availability is very important as it affects the number of tillers, number of ears per tiller, number of grains per ear, thousand grain weight, and $\mathrm{N}$ concentration in the grains (Darwinkel 1978; Osman et al. 2012). Although winter wheat can root deep (up to $2.0 \mathrm{~m}$, see Table 1), the nutrients that accumulate in the grains need to be taken up during a crop stage when the nutrient uptake of the root system has already decreased (Spiertz and Ellen 1978). Kichey et al. (2007) estimated that $\mathrm{N}$ uptake after anthesis can range from 5 to $50 \%$ of grain N. Another strategy of the wheat plant to accumulate nutrients in the grain is the reallocation (remobilization) from vegetative plant parts (stem and leaves) where they have been sequestered before flowering, resulting in the senescence of those vegetative plant parts (Sinclair and De Wit 1975). Part of these sequestered nutrients cannot be reallocated as they have been incorporated in cell wall material that cannot be broken down by the plant itself. At maturity, for most grain crops, a large percentage (approx. 50\% for maize up to $75 \%$ for wheat) of the total above-ground $\mathrm{N}$ is in the grains (Linquist et al. 1992; Kramer et al. 2002).

Maize differs from wheat crops as it is a monoecious plant with separate male (staminate) flowers on the tassel at the end of the main stem and female (pistillate) flowers on the ear at the end of a branch halfway up the main stem, but on the same plant. The rate of uptake of nitrogen by maize is low during early development and increases at tasseling. Although only relatively small amounts of fertilizers are required during the very early stages of plant growth, high concentration of nutrients in the root zone at that time is beneficial in promoting early growth (Ritchie et al. 1993). $\mathrm{N}$ fertilization increases the number of leaves per plant, the leaf area and stem diameter, plant height, and total above soil fresh and dry weight (Ciampitti and Vyn 2011). The N remobilization process starts from stem and older, lower leaves to sustain the leaf $\% \mathrm{~N}$ of the upper layers, especially around the ear leaf, but is also affected by other factors such as water and light stress. The ears have very high concentrations of nitrogen during their initiation but that nitrogen is diluted rapidly by starch accumulation during grain filling, although the total amount of nitrogen in the ears is increasing rapidly (Ciampitti and Vyn 2013). These authors concluded that grain $\mathrm{N}$ is the result of the interplay between the following aspects: (1) shoot $\mathrm{N}$ remobilized at reproductive stage and whole-plant $\mathrm{N}$ uptake at reproductive stage, (2) the ratio between the nitrogen in the grains and the nitrogen in the whole plant (NHI), and (3) grain yield and \%grain $\mathrm{N}$.

Oilseed rape differs physiologically from wheat as in the vegetative phase, $\mathrm{N}$ directly affects the branching and thus the number of seeds of oilseed rape (Labra et al. 2017). Besides, oilseed rape has more options to compensate $\mathrm{N}$ stress during reproductive stage, e.g., by branching and varying the number of siliques per branch or the number of seeds per silique (Berry et al. 2010; Diepenbrock 2000). Another difference is that during seed filling, there is no leaf photosynthesis as oilseed rape drops all of its leaves between flowering and maturity whereas wheat can profit from a long stay-green phase of the flag leaf for continuous leaf photosynthesis and supply of $\mathrm{N}$ to build up the proteins and starch (Kessel et al. 2012). However, in the case of oilseed rape, the photosynthesis of the siliques contributes substantially to grain filling (Diepenbrock 2000), especially for the siliques in the top of the canopy (authors' observation). This is also true for wheat through ear photosynthesis (Maydup et al. 2010; SanchezBragado et al. 2016) or photosynthesis by the awns (Sanchez-Bragado et al. 2016). Labra et al. (2017) 
demonstrated that nitrogen plays a crucial role in the branching behavior of oilseed rape and in number of siliques and number of seeds per silique. But, the seed size or oil content in the seed was not affected significantly. Not only photosynthesis of siliques but also that of stems plays an important role in providing the assimilates necessary for seed filling (Diepenbrock 2000; Labra et al. 2017). However, this cannot last long as the organic nitrogen necessary for seed formation also must come from translocation from these organs (Schjoerring et al. 1995).

In the next section we will discuss the extent to which such morphological and physiological differences in $\mathrm{N}$ uptake and utilization processes among the discussed crop species will lead to different traits related to NUE.

\section{Crop-specific traits related to nitrogen use efficiency: a breeding perspective for different crops}

To improve the NUE of cultivars, the above-described cropspecific differences in $\mathrm{N}$ uptake and utilization strategies need to be taken into account. Below, we will discuss which traits are found to contribute to NUE in the different crop species: spinach, lettuce, cabbage, potato, wheat, maize, and oilseed rape.

\subsection{Spinach}

Chan-Navarrete et al. (2014) analyzed the traits related to NUE under optimal and low $\mathrm{N}$ in controlled conditions (hydroponic system in greenhouse) and analyzed root dry weight and shoot dry weight, root/shoot ratio, leaf area, specific leaf area, chlorophyll content, and shoot $\mathrm{N}$ content. Path analysis revealed that the variables leaf area, root dry weight, chlorophyll content, and specific leaf area explained the variation in NUE between 22 commercial cultivars under low and high $\mathrm{N}$ to a large extent, and that under both conditions, leaf area had the highest direct effect on NUE, while at the low $\mathrm{N}$ regime, the direct effect of specific leaf area also was important. Biemond (1995) found in his experiment with one spinach cultivar that the rate of leaf appearance was hardly affected by $\mathrm{N}$ differences, whereas ChanNavarrete et al. (2014) found significant genetic variation among 22 cultivars. The latter also showed that slow and fast growing genotypes differed in their strategy of utilizing $\mathrm{N}$. The fast growers in general were more responsive to high $\mathrm{N}$ conditions and had a higher NUE than slow growers under high $\mathrm{N}$, but fast growers lacked the capacity to increase NUE under $\mathrm{N}$ limitation. The fast growing cultivars did not utilize the available $\mathrm{N}$ as efficiently as the slow growers. The ability of slow growers to increase NUE under low $\mathrm{N}$ could be an interesting trait for improving spinach cultivars for production under low N supply. Chan-Navarrete et al. (2014) found that selection for NUE under high $\mathrm{N}$ misses good performers under low $\mathrm{N}$.

In Chan-Navarrete et al. (2016), the genetic base for NUE in spinach was analyzed for NUE ( $g$ shoot dry weight $g^{-1} \mathrm{~N}$ ) and NUE-related traits using a mapping population (a random set of F2:3 families) grown in a greenhouse under low and high $\mathrm{N}$ conditions in a hydroponics system using an Ingestad $\mathrm{N}$-addition model to acquire a steady state $\mathrm{N}$ nutrition level (Chan-Navarrete et al. 2014). Interval mapping analysis detected 19 quantitative trait loci (QTLs) under high $\mathrm{N}$ and 20 QTLs for NUE-related traits under low N. Some QTLs were found under both $\mathrm{N}$ levels and some were specific for one of the two N levels. One QTL controlling NUE was found at linkage group $\mathrm{P} 01$ at low $\mathrm{N}$ conditions and explained 17.0\% of the phenotypic variation. This QTL co-localized with multiple QTLs for shoot dry weight, leaf area, shoot fresh weight, chlorophyll content, flowering, leaf number, and stem length. At high N conditions, no QTL for NUE was detected (ChanNavarrete et al. 2016). When the relationships between NUE and 12 NUE-related traits were analyzed separately for low and high $\mathrm{N}$ based on genotype means, the correlation between $\mathrm{N}$ treatments for NUE was moderate, reflecting a significant genotype $\times \mathrm{N}$ interaction. At both $\mathrm{N}$ treatments, NUE was highly correlated with shoot fresh weight, shoot dry weight, leaf area, and root dry weight. There was a moderate negative correlation between NUE and the physiological traits specific leaf area and root/shoot ratio. Chlorophyll content at 28 days showed no significant correlation to NUE at low N, but was significantly correlated with NUE under high $\mathrm{N}$ as well as with shoot fresh and dry weight, root dry weight, and leaf area (Chan-Navarrete et al. 2016). It should be noted that these QTLs were found under highly controlled conditions and the relevance of these QTLs under field conditions needs to be tested.

\subsection{Lettuce}

A short-cycle crop such as lettuce needs to be able to capture and exploit the available $\mathrm{N}$ as efficiently as possible, in a short period, and at an early stage. For such crops, there is a need to breed for early vigor and early root development (Andresen et al. 2016).

Most genetic studies on uptake efficiency in lettuce have included wild lettuce types which differ to a large extent from the cultivated lettuce with respect to above- and below-ground traits; e.g., sown wild lettuce has a long taproot while transplanted lettuce has a small root system (Johnson et al. 2000; Hartman et al. 2014). When N stress occurs in a transplanted lettuce crop in the upper soil layer $(0-20 \mathrm{~cm})$, roots can elongate and increase root length density at deeper soil layers to capture more N (Kerbiriou et al. 2013a). Kerbiriou et al. (2013b) showed that lettuce cultivars with higher root weight and rooting depth resulted in higher yields. However, 
one of the tested cultivars had the highest physiological use efficiency ( $\mathrm{g}$ dry matter produced per $\mathrm{g} \mathrm{N}$ accumulated in the head) and gave the most stable yield across trials despite a relatively small root system. This demonstrates the complexity of nitrogen use efficiency even in relatively simple crop stands.

Kerbiriou et al. (2016) studied the genetic control of resource capture and resource use efficiency of commercial (transplanted) lettuce cultivars based on several field trials by association mapping (Kerbiriou et al. 2016). Significant genetic variation was found for fresh and dry weight yields, and plant $\mathrm{H}_{2} \mathrm{O}$ (i.e., the amount of water accumulated in the above-ground plant) and plant $\left[\mathrm{H}_{2} \mathrm{O}\right]$ as well as the amount of nitrate left in the different soil layers and across the whole soil profile from 0 to $40 \mathrm{~cm}$ as a proxy for $\mathrm{N}$ taken up. Kerbiriou et al. (2016) showed that genetic variation was best expressed under limiting conditions. Under optimal conditions, the highest dry matter production and NUE were achieved but no genetic variation was found for NUE. There were significant marker-trait associations identified across trials for below-ground and shoot traits but associations varied in number and position depending on the trial conditions (Kerbiriou et al. 2016; Fig. 5). Nitrate left across the full soil profile of $40 \mathrm{~cm}$ and in each layer showed the most marker-trait associations across the environment (in numbers and in consistency across the profile and layers). Genotype $\times$ environment interactions $(G \times E)$ were strong stressing the importance of environmental factors for the expression of the traits included; moreover, for physiological mechanisms regulating shoot and root growth were largely impacted by environmental conditions and thus varied per trial. This shows a certain level of plasticity of the plants and makes it hard to generalize outcomes. Kerbiriou et al. (2014) pointed out that plasticity of below-ground traits in space and time might be more important than below-ground traits per se; traits that are expressed in one environment may impair the expression of other traits of importance in other environments. Moreover, observed phenotypic effects may be controlled by numerous quantitative trait loci, of which the individual expression greatly varies with environment. This need for a high level of plasticity in adaptation to the environment especially under low-input conditions among short-cycle crops is also confirmed by other authors, e.g., Hodge (2004).

\subsection{Cabbage}

Cabbage has been shown to root to large depths (up to $2 \mathrm{~m}$ ) and leaves little $\mathrm{N}$ behind after harvest resulting in high $\mathrm{N}$ recovery from the soil. Therefore, Thorup-Kristensen (2006a) suggested that for cabbage, most benefits can be expected from improving utilization efficiency. These utilization processes and the ratio between outer and inner leaves (head) and related processes differed for early, mid-early, and late cultivars (Schulte auf'm Erley et al. 2010). These authors showed in their experiments with eight cultivars that these genotypes differed in NUE but did not differ in $\mathrm{N}$ uptake under low $\mathrm{N}$ availability; the difference was mainly determined by the partitioning of dry matter to the heads (harvest index). Besides harvest index and the rate of leaf senescence and leaf loss, also $\mathrm{N}$ harvest index was correlated to NUE (Schulte auf'm Erley et al. 2010). According to Schulte auf'm Erley et al. (2010), cultivars with a high NUE had a high number of shed leaves and therefore a low number of
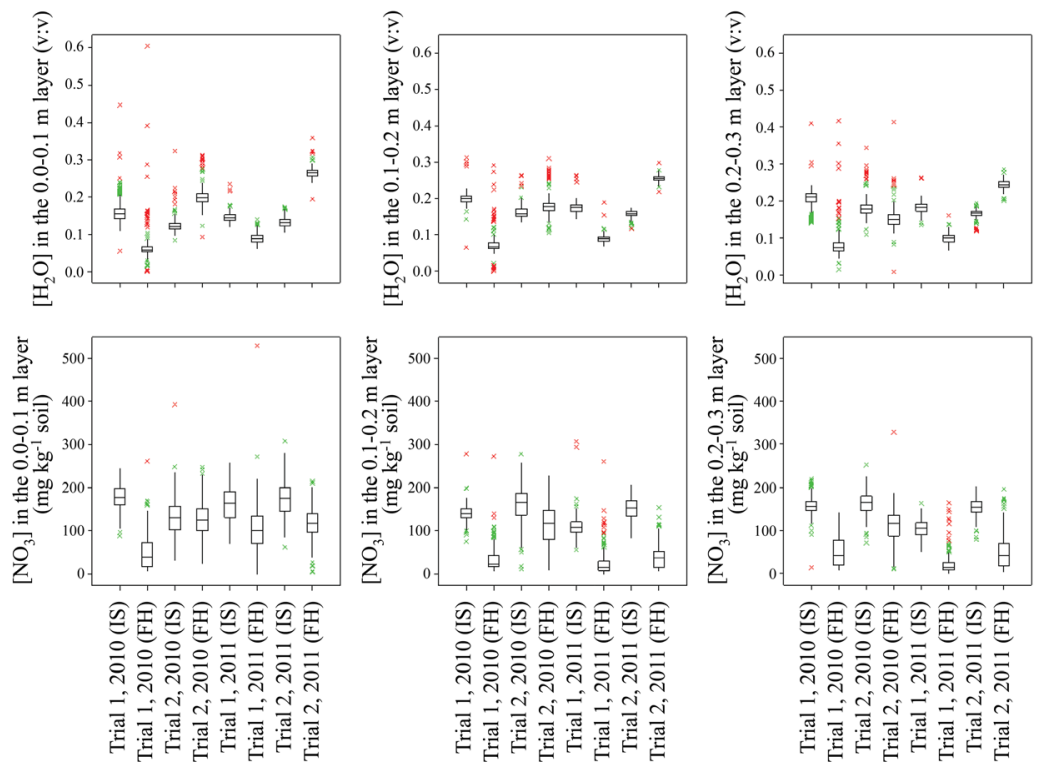

要

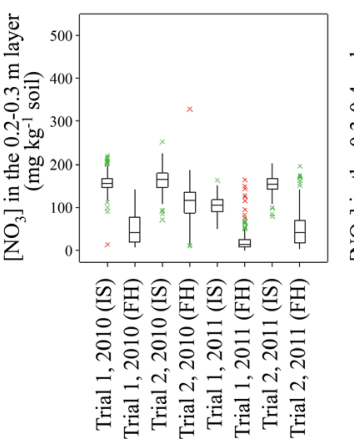

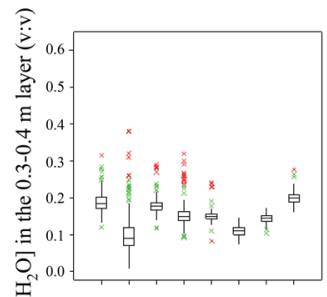
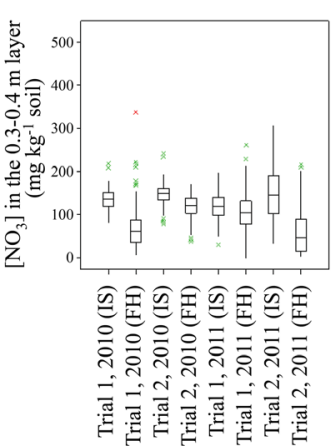

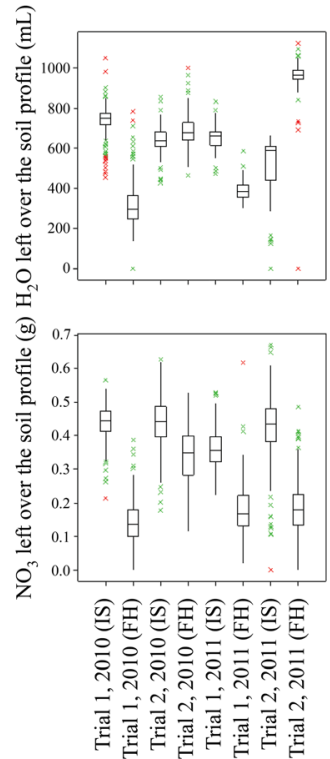

Fig. 5 Boxplots of below-ground traits $\left(\left[\mathrm{H}_{2} \mathrm{O}\right],\left[\mathrm{NO}_{3}\right], \mathrm{H}_{2} \mathrm{O}\right.$, and $\mathrm{NO}_{3}$ left across the soil profile) at different soil layers $(0-40 \mathrm{~cm}$ depth) for a population of 142 lettuce cultivars in 4 trials ( 2 trials in 2010, 2 trials in
2011) and 2 sampling dates (IS = intermediate sampling; $\mathrm{FH}=$ final harvest). Adapted from Kerbiriou et al. (2016) 
wrapping leaves. Late-maturing genotypes developed more leaves until heading than early cultivars, but leaf numbers increased between heading and maturity for some early genotypes and decreased for late genotypes. Especially among late cultivars under both high and low N, many leaves had senesced at harvest time contributing to a high harvest index and remobilization of both dry matter and $\mathrm{N}$ from the older leaves to the head. The mid-late cultivars under low $\mathrm{N}$ continued to form wrapping leaves resulting in less dry matter allocation to the head. The explanation for this was that early cultivars can suffer from low temperature and low $\mathrm{N}$ availability leading to few wrapping leaves at the start of head formation. This would imply that breeding should emphasize early vigor and tolerance to low temperatures to contribute to higher NUE (Schulte auf'm Erley et al. 2010).

Future research should explore the most ideal ratio between outer leaves and head (harvest index) in relation to NUE, and the extent to which leaf attitude and number of leaves play a role. In addition, it will be interesting to assess whether other selection criteria can be applied, e.g., leaf area index, specific leaf area index, nitrate reductase activity, and/or chlorophyll content or chlorophyll fluorescence.

\subsection{Potato}

The calculation of NUE parameters in potato is more complex than for other crops such as cereals due to the usual total decay of the above-ground biomass of the potato crop at harvest time (Swain et al. 2014). Therefore, Ospina et al. (2014) and Tiemens-Hulscher et al. (2014) analyzed the perspectives to breed for NUE in potato by studying the total canopy development including parameters such as (i) time until maximum canopy cover, (ii) percentage of maximum canopy cover, (iii) period of maximum canopy cover, (iv) start senescence, (v) time to complete crop senescence, and (vi) area under the canopy cover progress curve.

The canopy development component traits were useful to understand the different responses to $\mathrm{N}$ and to identify relevant traits correlated with NUE. There was much variation for these component traits among a large set (189) of cultivars (Ospina et al. 2014). High nitrogen prompted the increase in leaf area leading to a faster buildup of the canopy including a steeper increase in leaf area, an earlier time point to reach maximum soil coverage, a longer phase of maximum canopy cover, and delayed canopy senescence leading to a higher percentage of soil cover allowing a larger portion of the light to be intercepted (Fig. 6). The area under the canopy cover progress curve, the percentage of maximum soil cover, and the period of maximum soil cover are the most important parameters. The area under the canopy cover progress curve can be measured quite accurately but is not easy to assess in the field, as it requires frequent observations; the maximum soil cover and the period of maximum soil cover (from start of maximum soil cover to start of senescence) can be relatively easily assessed in the field (Tiemens-Hulscher et al. 2014). Selection can best be conducted under low $\mathrm{N}$ conditions (approximately $100-120 \mathrm{~kg} \mathrm{~N} / \mathrm{ha}$ ) as this allows a better expression of discriminative traits (Ospina et al. 2014; TiemensHulscher et al. 2014).

However, the main factor explaining NUE was maturity; see Fig. 6. Yield and NUE increase from early- to latematuring cultivars (Zebarth et al. 2004; Ospina et al. 2014; Swain et al. 2014; Tiemens-Hulscher et al. 2014). However, this is only valid if the growing season is long enough to allow a yield profit from the prolonged and larger canopy of the late maturity type. Under management with crop protection against late blight (Phytophthora infestans), the late varieties have a longer growing period and an extended period of maximum canopy cover and photosynthesis activity potentially leading to higher yields and higher NUEs (Ospina et al. 2014; Swain et al. 2014; Tiemens-Hulscher et al. 2014).

As the canopy has decayed at harvest, the harvest index cannot be used as a measurement of maximum productivity of the canopy, but instead, the soil coverage yield index was used, i.e., the ratio of the area under the canopy cover progress curve and yield. Ospina Nieto (2016) showed that this trait had a QTL different from those related to yield or area under the canopy cover progress curve and that this QTL was also different from those detected for maturity.

Nitrogen use efficiency decreases with more $\mathrm{N}$ input. Selection could combine performance under low input and response to $\mathrm{N}$ fertilizer when growth conditions are more favorable. In Fig. 7, the scatter points, reflecting the agronomic nitrogen use efficiency of a large set of cultivars grown at two different levels of nitrogen supply, plotted against the yield at low nitrogen supply, are divided into four quadrants by using the mean values of both variables as a crossing point for the two axes. Quadrant II shows the genotypes that perform well under low $\mathrm{N}$ and show a good response to $\mathrm{N}$. The majority of the genotypes in this quadrant were late or intermediate. Under low N, early genotypes did not perform well and the response to extra nitrogen did not seem to be maturity dependent. On the other hand, genotypes with good yield under low $\mathrm{N}$ also tended to have a good yield under high $\mathrm{N}$. Ospina et al. (2014) and Tiemens-Hulscher et al. (2014) demonstrated that there is considerable variation to select for NUE genotypes within each maturity type.

To analyze the genetic basis of the traits related to NUE, Ospina (2016) used the parameters describing the canopy development for a genome wide association study including some 200 cultivars, grown during two years and at two N levels. The majority of the marker-trait associations were year dependent, with only 166 associations (out of 950) detected in both years, reflecting a strong influence of environmental conditions. Overall, 20 traits (out of 24) showed associations that were present in both years of the experiments. More marker- 
Soil coverage $(\%)$

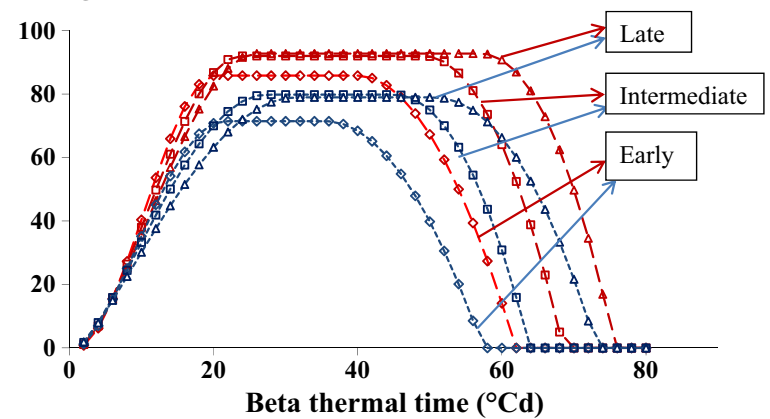

Fig. 6 Potato canopy development curves under low (blue lines; short dashes) and high (red lines; long dashes) N, for early (diamonds), intermediate (squares), and late (triangles) cultivars. The unit along the $X$-axis is thermal days $\left({ }^{\circ} \mathrm{Cd}\right)$ calculated from the beta thermal time and on the $Y$-axis the percentage soil coverage is shown. Note that one thermal day is equal to a day with optimal temperature. Days with sub- or supraoptimal temperatures contribute less than 1 day to the sum of thermal days. Adapted from Ospina et al. (2014)

trait associations were detected under high $\mathrm{N}$ than under low $\mathrm{N}$ (69 and 47, respectively). This QTL $\times \mathrm{N}$ interaction indicated that limiting $\mathrm{N}$ conditions resulted in a change in the importance of the associated genomic regions and therefore in differences in genotypic response. About $30 \%$ of the associations were common to both $\mathrm{N}$ levels (50 out of 166). Most of these marker-trait associations common to both $\mathrm{N}$ levels were maturity related $(88 \%)$.

Little is known about NUpE in potato. Zebarth et al. (2004) found under high $\mathrm{N}$ that there was larger genetic variation in $\mathrm{N}$ uptake capacity (plant $\mathrm{N}$ accumulated) than in NupE. To what extent root architecture plays a role in $\mathrm{NUpE}$ in potato has also not been extensively investigated. Swain et al. (2014) showed that there were significant differences in early $\mathrm{N}$ uptake among two cultivars but this was not reflected in soil samples in the upper $30 \mathrm{~cm}$, so the authors suggested that there were differences in depth of rooting that could have caused the difference but this was not measured. Iwama (2008) concluded from various experiments that late cultivars had more root biomass than early cultivars, but also that there was genetic variation within maturity groups for root biomass.

\subsection{Winter wheat}

Much research has been conducted on defining traits related to NUE improvement in winter wheat, and many traits have been identified but underlying relationships have not always been fully understood (Hirel et al. 2011). Foulkes et al. (2009) concluded in their extensive review that for both feed and bread wheat types, the following traits can be addressed to improve NUE in wheat with respect to NUpE: increased root length density at depth and a high capacity for $\mathrm{N}$ accumulation in the stem, potentially associated with a high maximum $\mathrm{N}$-uptake rate. With respect to NUtE, these authors listed the following traits to be included as selection criteria: low leaf lamina $\mathrm{N}$ concentration, a more efficient post-anthesis remobilization of $\mathrm{N}$ from stems to grain, but less efficient remobilization of $\mathrm{N}$ from leaves to grain, both potentially associated with delayed senescence. Gaju et al. (2011) found that the timing of the onset of senescence explained $86 \%$ of the variation in NUtE under low $\mathrm{N}$, but no significant correlation between onset of

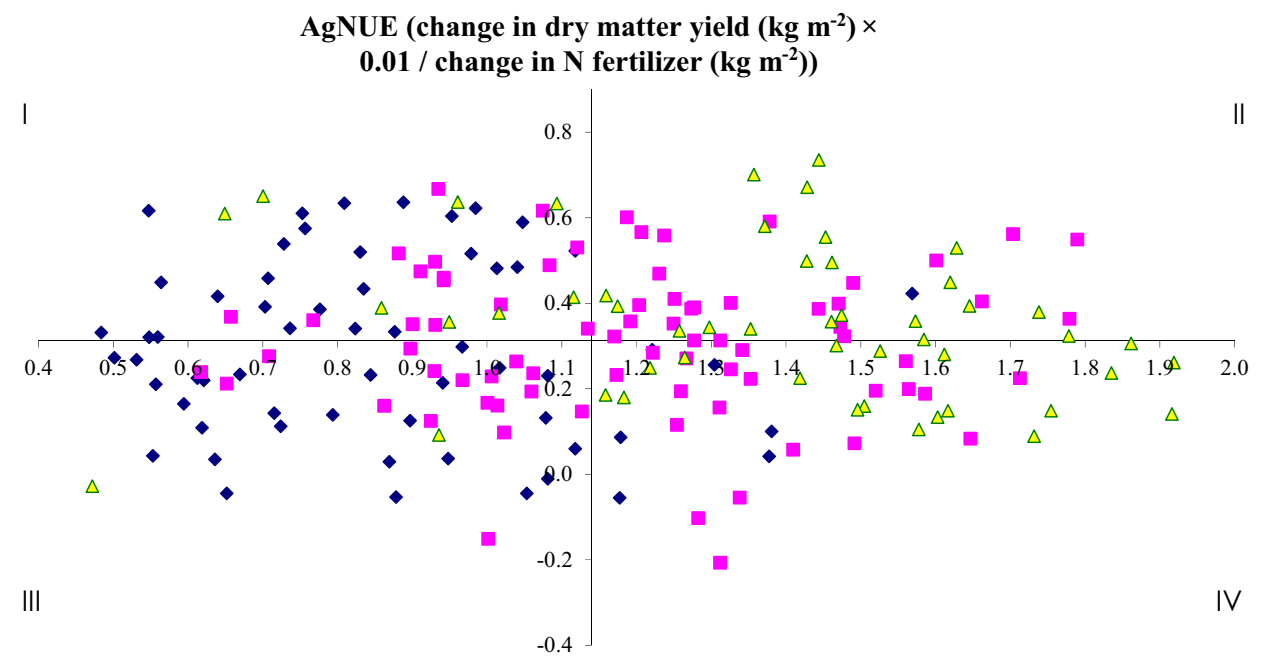

Dry matter yield (Low N) kg m ${ }^{-2}$

Fig. 7 Relationship between the performance of genotypes under low nitrogen input ( $X$-axis) and the response to additional $\mathrm{N}$ expressed in agronomic nitrogen use efficiency (AgNUE) when changing the $\mathrm{N}$ input from low to high, i.e., the yield increase (in $\mathrm{kg}$ dry matter per $\mathrm{m}^{-2}$ ) $\times 0.01$ divided by the additional $\mathrm{N}$ fertilizer (in $\mathrm{kg} \mathrm{per}^{-2}$ ). Quadrant $\mathrm{I}=$ high response to additional $\mathrm{N}$ but low yield under low $\mathrm{N}$;
Quadrant II = high response to additional $\mathrm{N}$ and high yield under low $\mathrm{N}$. Quadrant III = low response to additional $\mathrm{N}$ and low yield under low $\mathrm{N}$; Quadrant IV = low response to additional $\mathrm{N}$ and high yield under low $\mathrm{N}$. Diamonds: early cultivars; squares: intermediate cultivars; triangles: late cultivars. Adapted from Ospina et al. (2014) 
senescence and NUtE nor with grain yield was detected under high $\mathrm{N}$.

In Gaju et al. (2014), these authors further investigated the relationships among $\mathrm{N}$ accumulation, $\mathrm{N}$ partitioning, and $\mathrm{N}$ remobilization in winter wheat and concluded that genetic variation in grain yield and grain $\mathrm{N} \%$ under high $\mathrm{N}$ input conditions was mainly influenced by pre-anthesis $\mathrm{N}$ accumulation and to a less extent by post-anthesis $\mathrm{N}$ remobilization. At low $\mathrm{N}$ growing conditions, lamina $\mathrm{N}$ remobilization seemed to cause genetic variability in grain $\mathrm{N} \%$ but not in grain yield (Gaju et al. 2014).

With respect to cultivars grown for feed, Foulkes et al. (2009) indicated that reduced grain $\mathrm{N}$ concentration can be crucial to increase NUE whereas for bread-making cultivars, it is the opposite. For the latter, improving NUE is correlated with high capacities for uptake and assimilation of $\mathrm{N}$, with high post-anthesis $\mathrm{N}$ remobilization efficiency and/or specific grain protein composition. Barraclough et al. (2010) confirmed this and concluded that grain yield, grain $\% \mathrm{~N}$, total $\mathrm{N}$ uptake, and $\mathrm{N}$ harvest index are the most important variables to improve NUE in wheat.

Various authors have discussed the relative importance of NUpE and NUtE for wheat. Osman et al. (2012) argued that in order to increase grain $\mathrm{N}$ content in bread wheat, an increase in $\mathrm{NUpE}$ is more effective as increasing NUtE would decrease grain protein content. This last aspect was also noted by Barraclough et al. (2010) and Górny et al. (2011): they found a negative correlation between grain-NUtE and grain $\% \mathrm{~N}$. There are a few studies that analyzed the genetic variation in NUtE distinguishing between remobilization efficiency ( $\mathrm{N}$ in grains taken up until anthesis divided by $\mathrm{N}$ present in plant biomass at anthesis) and translocation efficiency ( $\mathrm{N}$ in grains absorbed after anthesis divided by total nitrogen absorbed after anthesis) (e.g., Kichey et al. 2007; Baresel et al. 2008). From the latter studies, it was concluded that the genetic variation among European genotypes in both remobilization and translocation efficiency was limited. Gaju et al. (2011) found in their experiments with 16 winter wheat cultivars under various growing conditions that the variation in NUE under low $\mathrm{N}$ was mainly due to variation in NUtE rather than in NUpE, but at one site, it was the opposite under low N. Le Gouis et al. (2000), however, referred to research outcomes that have shown genetic variation in winter wheat for $\mathrm{NUpE}$ and also for NUtE expressed as the ratio of grain yield to total plant N, and concluded that $\mathrm{N}$ uptake better accounted for the variation in grain yield than $\mathrm{N}$ utilization; under low input, all variation in NUE was explained by NUpE whereas under high input, it explained approximately two thirds of the variation in NUE. Also, Ortiz-Monasterio et al. (1997) found in trials in Mexico comparing tall versus semi-dwarf cultivars that with modern semi-dwarf cultivars, grain yield as well as NUE was improved including both NUpE and NUtE and that the relative importance of these two components was affected by the level of applied N. The improved NUE came from improved NUpE under low $\mathrm{N}$ whereas improved NUtE was the most important factor under high $\mathrm{N}$. These trials also showed that modern semi-dwarf cultivars do not need more $\mathrm{N}$ than older cultivars but that, instead, modern cultivars are more responsive to $\mathrm{N}$ when available.

The harvest index is improved by semi-dwarf cultivars but also among semi-dwarf cultivars, genetic variation in total $\mathrm{N}$ uptake and grain-NUtE was found (Barraclough et al. 2010). These authors showed that some short varieties were better capable of taking up $\mathrm{N}$ (up to $31-38 \mathrm{~kg} / \mathrm{ha}$ more $\mathrm{N}$ than the worst) and that grain-NUtE was $24-42 \%$ better, depending on $\mathrm{N}$ rate; up to $77 \%$ of the variation in grain-NUtE was accounted for by yield. Of all significant interactions between genotype, year, and $\mathrm{N}$ rate, only "year $\times \mathrm{N}$ rate" made an important contribution to the variation in grain-NUtE.

Górny et al. (2011) investigated the inheritance of the components of NUE (NUpE, NUtE, NHI, grain dry weight produced per unit of $\mathrm{N}$ accumulated in grains) and concluded that the broad-sense heritabilities did not exceed the $60 \%$ for the NUE components (ranged rather between 20 and 40\%) indicating moderate genetic variability and strong environmental influences. The $\mathrm{G} \times \mathrm{N}$ interactions on these NUE components were indeed often large. Górny et al. (2011) stressed that although the inheritance of NUE components under high $\mathrm{N}$ is higher and therefore seemingly more attractive, it is important to select under low $\mathrm{N}$ and to try to pyramid genes for various components taking advantage of additive effects to improve NUE and for better adaptation to low N.

To improve NUpE, it was found that cultivars with a larger root system resulted in higher $\mathrm{N}$ uptake and did not necessarily decrease grain yield (see, e.g., Ehdaie et al. 2010; Andresen et al. 2016). Andresen et al. (2016) showed that among nine spring wheat cultivars in 2-m-deep tube rhizotrons, the total root biomass could differ almost twofold, and that also the spatial distribution of their root systems in the soil differed substantially. They specifically argued for improving root growth in the initial growth phase as not much volume is exploited at that phase.

\subsection{Maize}

During the past decades, agronomists have increased maize grain yield to a large extent by changing many management aspects, e.g., increasing fertilizer input and increasing plant density. In that context, breeders have very much focused on improving the responsiveness to nitrogen fertilization and increasing stress tolerance to higher plant-plant interactions in higher plant density stands. Breeders achieved such progress by selecting for maintenance of high storage capacity of $\mathrm{NO}_{3}{ }^{-}$ in the leaves, leaf longevity (stay-green) during remobilization for good grain filling, and maintenance of individual-plant $\mathrm{N}$ uptake with extended reproductive-stage accumulation (Hirel 
et al. 2001; Tollenaar and Lee 2011; Ciampitti and Vyn 2011; Chen et al. 2016).

Several authors found that leaf longevity is also a suitable and important trait to select for NUE cultivars for both low and high N (Bänziger and Lafitte 1997; Hirel et al. 2001; Coque and Gallais 2007). Racjan and Tollenaar (1999) found that leaf longevity was correlated to a larger source/sink ratio during grain filling and stressed that the process of remobilization was more important than the level of $\mathrm{N}$ fertilization when cultivars were compared.

In a review on genetic variation for NUE in maize, Gallais and Coque (2005) concluded that the $\mathrm{G} \times \mathrm{N}$ was relatively low as a relatively high correlation was found between yield under high and low $\mathrm{N}$ if yield differences were not more than $35 \%$ between high and low N. However, the expression of the genetic variation was different under these conditions: under low N, both NUpE and NUtE were important, whereas under high $\mathrm{N}$, mainly variation in NUpE played a role (Moll et al. 1982; Presterl et al. 2002; Gallais and Coque 2005). Geiger (2009) concluded that the relative importance of NUpE or NUtE depended largely on the genetic background of cultivars and was maybe based on different physiological mechanisms. Gallais and Coque (2005) found that under low $\mathrm{N}$, the $\mathrm{G} \times \mathrm{N}$ interaction was due to number of kernels which led to the recommendation to select for reduced kernel abortion in early stages of embryo development and also to the conclusion that remobilization played an important role under low N. Geiger (2009) found that genotypes with low grain protein performed well in NUtE and those with high grain protein level were good in NUpE. Similar findings were described by Uribelarrea et al. (2007) who found that selection for either high or low grain protein can lead to genotypes that are similar in overall NUE at maturity but are different in the underlying mechanisms: high protein strains had the highest values for $\mathrm{N}$ uptake efficiency and the low protein strains the lowest NupE. Geiger (2009) pointed out several stress indicators that can be associated with NUE such as anthesis-silking interval, leaf chlorophyll concentration, number of ears per plant, and also number of kernels per ear (as mentioned by Gallais and Coque 2005).

There seems to be sufficient genetic variation available in European maize cultivars for improving NUE under low N (Coque and Gallais 2007). Ciampitti and Vyn (2013) compared older maize cultivars (released before 1990) and more recent cultivars and concluded that with increasing yield over time, grain $\mathrm{N}$ concentration has decreased. They also concluded that for the modern cultivars, reproductive $\mathrm{N}$ contributed relatively more to grain $\mathrm{N}$ whereas for the older cultivars, reproductive and remobilized $\mathrm{N}$ contributed equally to grain $\mathrm{N}$. The remobilized $\mathrm{N}$ was primarily associated with wholeplant $\mathrm{N}$ uptake (vegetative $\mathrm{N}$ ), which was constant over time of breeding, although the proportion of the remobilized $\mathrm{N}$ itself seemed to be driven by the ear demand, whereas the reproductive $\mathrm{N}$ seemed to be influenced by complex plant regulation processes (source/sink). Finally, they found that over time, stover $\mathrm{N}$ concentration gains mirrored the grain $\mathrm{N}$ concentration as the plant $\mathrm{N}$ uptake increased at maturity for both the older and modern cultivars.

\subsection{Oilseed rape}

Oilseed rape is $\mathrm{N}$ demanding and is considered less $\mathrm{N}$ efficient than wheat. This is caused by a $50 \%$ lower harvest index, a higher concentration of $\mathrm{N}$ in the seed, and a higher $\mathrm{N}$ harvest index (seed N/total crop N) compared to wheat (Diepenbrock 2000; Dreccer et al. 2000). Loss of N through leaf litter seems relevant and that is why some authors have included this trait in their research (Nyikako et al. 2014). There is also loss of $\mathrm{N}$ through seed shattering and there appears to be genetic variation for that trait as well (Morgan et al. 1998).

Kessel et al. (2012) referred to several strategies described in literature for investigating traits related to NUE: high harvest index and $\mathrm{N}$ harvest index, physiological efficiency of absorbed $\mathrm{N}$, or estimation of relative contribution of uptake and utilization efficiency to the total genetic variation in NUE.

Wiesler et al. (2001) discussed two ideotypes for N efficient cultivars, (a) an improved traditional ideotype with vigorous growth and high $\mathrm{N}$ uptake until flowering and efficient $\mathrm{N}$ retranslocation into the seeds during reproductive growth and (b) an alternative ideotype with comparatively slow growth and $\mathrm{N}$ uptake rates until flowering which continue during reproductive growth, and concluded that the latter gave the best $\mathrm{N}$ efficiency. This is also confirmed by Schulte auf'm Erley et al. $(2007,2011)$ who found that NUE (grain yield at low N) was positively correlated with delayed leaf senescence which contributed to continued root activity and $\mathrm{N}$ uptake. These authors considered-besides delayed leaf senescence-also a high efficiency in $\mathrm{N}$ uptake until flowering (for high $\mathrm{N}$ accumulation in young leaves) as very important. Thus, selection should target genotypes with late senescence that reallocate $\mathrm{N}$ efficiently from leaves to stems and seeds. In that context, Schulte auf'm Erley et al. (2011) stressed that the duration of $\mathrm{N}$ uptake is also important especially under low $\mathrm{N}$. In addition, Berry et al. (2010) pointed out more precisely that under low $\mathrm{N}$, the amount of $\mathrm{N}$ taken up after flowering was the most critical phase of $\mathrm{N}$ uptake to determine the yield differences between the varieties. In contrast, under high $\mathrm{N}$ conditions, variation in utilization (of accumulated $\mathrm{N}$ ) efficiency is not always more important than uptake efficiency and depends on the specific genetic material and environmental conditions (Schulte auf'm Erley et al. 2011; Nyikako et al. 2014). Nyikako et al. (2014) found that harvest index and NUE at low and high $\mathrm{N}$ were correlated suggesting that selection of short genotypes could improve NUE. They also found a correlation between $\mathrm{N}$ in dropped leaves and $\mathrm{N}$ use efficiency and uptake efficiency at low $\mathrm{N}$ but not at high N. Schulte auf'm 
Erley et al. (2011) also suggested that seed $\mathrm{N}$ concentration as proxy for $\mathrm{N}$ utilization efficiency could also be a promising candidate selection criterion especially under high $\mathrm{N}$ conditions.

Experiments comparing NUE of old and modern canola cultivars revealed that old cultivars did not provide interesting genetic resources for increased NUE; it is therefore recommended to use modern cultivars in breeding programs as they provide considerable genetic variation for this trait (see also Kessel et al. 2012). Balint and Rengel (2008) concluded that screening oilseed rape for NUE for breeding purposes would require assessment at maturity, as there was little consistency in NUE ranking between vegetative stage and maturity.

\section{Discussion}

In this paper, we reviewed different crop types (leafy and nonleafy vegetables, and grain-producing crops) and their traits involved in NUE. We will discuss whether the physiological differences among crop species with respect to crop duration, (re)allocation processes of $\mathrm{N}$, and dry matter to harvestable products (leaves, heads, tubers, or grains) and growth types (maturity types) lead to different traits contributing to NUE, and whether there are general characteristics that can be taken into account, and to what extent do crop traits for NUE differ for different management strategies (high versus low $\mathrm{N}$ ) impacting the choice of most appropriate selection environment for improving NUE. In Table 2, a summary is given of all discussed traits that have been included and prioritized in literature for the selected crops to improve NUE through breeding.

\subsection{Do physiological differences among crop species lead to different traits contributing to nitrogen use efficiency?}

\subsubsection{Nitrogen uptake efficiency}

Research on below-ground traits is complicated and only recently gaining interest among breeders. It should be noted that literature on below-ground traits in the selected crops is limited and not all available research on below-ground traits directly relates such traits to NUE which is the focus of our paper.

Across all the analyzed crop species, research results stress the need to address NUpE as an important component to improve NUE with the exception of cabbage; see Table 2. Cabbage has the ability to root quite deep and to deplete the soil to a large extent. This leads to the statement that the uptake of cabbage is already quite efficient (ThorupKristensen 2006a; Schulte auf'm Erley et al. 2010); however, research to date has only focused on a limited set of cultivars and to the best of our knowledge, no research has included a large set of genotypes to show whether there is variation that can be exploited in breeding to improve uptake efficiency in cabbage. Moreover, wheat can also root to the same depth as cabbage $(2.0 \mathrm{~m})$ and for wheat, much variation has been shown for $\mathrm{N}$ uptake and for root length densities at larger depth (beyond $1 \mathrm{~m}$ ) (Ehdaie et al. 2010; Andresen et al. 2016). Interestingly, Schulte auf'm Erley et al. (2010) found that $\mathrm{N}$ uptake under high $\mathrm{N}$ showed more variation whereas under low $\mathrm{N}$, no variation was found.

Specifically for all three grain crops, the duration of $\mathrm{N}$ uptake has proven to be important to maintain $\mathrm{N}$ uptake activity also during the reproductive phase of grain crops when normally, the root activity decreases, as relying on remobilization of leaf $\mathrm{N}$ is not sufficient especially not under low $\mathrm{N}$ (Wiesler et al. 2001; Gaju et al. 2011; Schulte auf'm Erley et al. 2011; Ciampitti and Vyn 2012; Gaju et al. 2014).

For short-cycle crops such as lettuce, more emphasis is put on early root formation (as the period to take up $\mathrm{N}$ is short), although Andresen et al. (2016) also advocated early vigor and early root development in winter wheat to maximize $\mathrm{N}$ capture in a period during which $\mathrm{N}$ can easily leach to deeper layers (see also Han et al. 2015). Specifically with respect to short-cycle crops, plasticity of root architecture has been discussed to be able to more rapidly respond to $\mathrm{N}$ stress conditions by extra root formation to capture the $\mathrm{N}$ available at depths beyond the soil layer between 0 and $20 \mathrm{~cm}$ where normally most lettuce and spinach roots have been formed (Schenk et al. 1991; Hodge 2004; Kerbiriou et al. 2014); long-cycle crops have more time to develop an extensive root system and require more root depth and root length densities at larger depth (Andresen et al. 2016). However, Trachsel et al. (2013) also discussed the importance of root plasticity in maize to be more adaptive under low-input conditions.

For various crops, research has shown genetic variation among cultivars within a crop species for various traits contributing to NUpE such as temporal and spatial root distribution (early root development, horizontal and vertical root growth) to be exploited in breeding programs (Trachsel et al. 2013; Andresen et al. 2016; Kerbiriou et al. 2016; Pestsova et al. 2016). But research on below-ground traits is complex and shows large $\mathrm{G} \times \mathrm{E}$ interactions. Schulte auf'm Erley et al. (2011) concluded in their research on NUE in oilseed rape that $\mathrm{N}$ uptake is the most important component for yield at all $\mathrm{N}$ levels but that mechanisms to achieve high $\mathrm{N}$ uptake could be manifold and future research should contribute to indicating which (combinations of) plant traits are most important and promising to include in plant breeding programs.

Research to improve the interaction with beneficial soil micro-organisms has not been the focus of this review as this science has only recently received strong attention in research and needs more exploration. However, genetic variation among cultivars for beneficial root-microbial relationships has been reported and can contribute to higher NUpE, for 


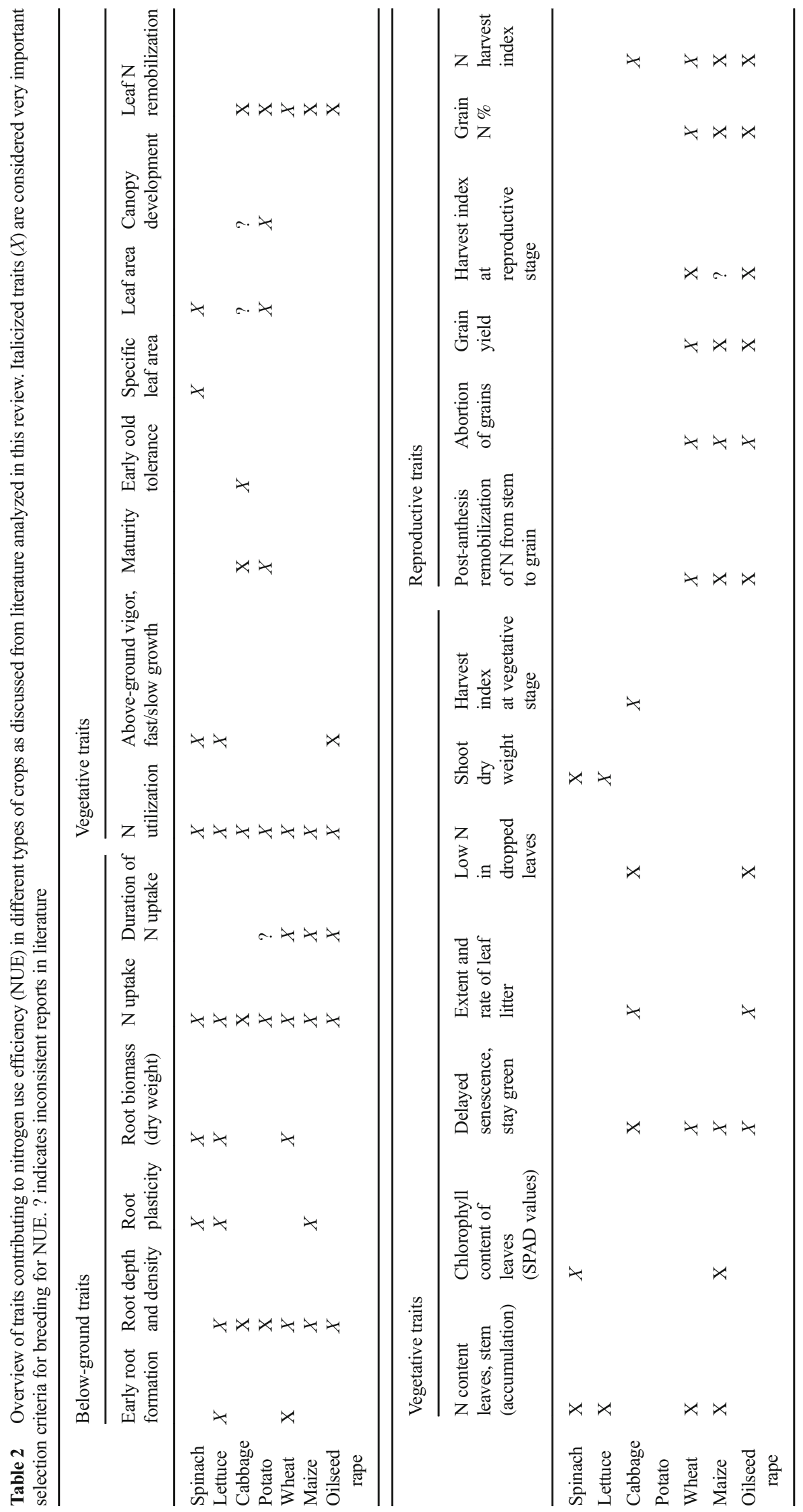


example in the case of onion in relation to mycorrhiza (Galván et al. 2011).

\subsubsection{Nitrogen utilization efficiency}

Literature indicates that NUtE is an important component to improve NUE in crops but there is much discussion on the relative importance of the manifold traits involved in NUtE and the variation in relative importance among crop species.

For grain crops, some specific vegetative traits such as leaf area, specific leaf area, and canopy development are not critical for NUE as they are for leafy (spinach, lettuce, cabbage) and non-leafy vegetables (potato); see Table 2 . On the other hand, leaf $\mathrm{N}$ remobilization is important for nearly all crops. Only for the very-short-cycle crops, such as spinach and lettuce, leaf $\mathrm{N}$ remobilization is not important as they are harvested before leaf senescence occurs. However, even in spinach surplus $\mathrm{N}$ is stored in vacuoles and can be utilized as source under $\mathrm{N}$ stress conditions but this is not the main factor for NUtE (Chan-Navarrete et al. 2014). For long-cycle crops such as cereal crops, but also for cabbage and potato, leaf $\mathrm{N}$ remobilization is essential as (next to $\mathrm{N}$ uptake) leaf $\mathrm{N}$ is a source for the younger leaves and also for the organs that are not photosynthetically active such as the inner leaves of the cabbage head, or potato tubers and grain reproductive organs. Therefore, measuring $\mathrm{N}$ content of leaves and stems gives information on available source function. For leafy vegetables, $\mathrm{N}$ content of leaves is more related to quality and color of the harvested produce.

Leaf senescence is part of the $\mathrm{N}$ remobilization strategy of plants with a longer growth cycle. Research on the importance of delayed (complete) leaf senescence to maintain photosynthesis activity for head, tuber, or grain filling and to feed the roots with assimilates to maintain root uptake activity is abundant (Schulte auf'm Erley et al. 2007; Foulkes et al. 2009; Ciampitti and Vyn 2012). Also, in potato, a long period between maximum soil cover and canopy senescence has been identified as an important parameter for NUE (Ospina et al. 2014). For a different reason, delayed leaf senescence can be of importance for spinach as it provides a wider harvest window for good quality of fresh produce especially under lowinput conditions.

The importance of the number and rate of leaf shedding seems typical for the brassica crops (cabbage and oilseed rape) (Schulte auf'm Erley et al. 2010, 2011). In this context, it is also mentioned that a low $\mathrm{N}$ content of the dropped leaves means that much of the $\mathrm{N}$ taken up has been reused and this contributes to NUE (e.g., Nyikako et al. 2014). Similar to leaf loss, also, selecting for genotypes that allow less abortion of grains can contribute to a larger HI and NUtE (Morgan et al. 1998; Gallais and Coque 2005).

\subsubsection{Nitrogen uptake versus nitrogen utilization efficiency}

The relative importance of NUpE versus NUtE has been discussed in many papers, especially in the research on grain crops resulting in contrasting results (Le Gouis et al. 2000). Most research points out that under low $\mathrm{N}, \mathrm{NUpE}$ is most important than under high $\mathrm{N}$, but exceptions are also shown. Geiger (2009) argued that the relative importance of $\mathrm{NUpE}$ and NUtE for oilseed rape very much depends on the genetic base of genotypes related to different physiological mechanisms in response to $\mathrm{N}$ level. Górny et al. (2011) pointed to the negative correlation they found in winter wheat between NUtE or NUpE and \% grain $\mathrm{N}$ and suggested that this might be related to the fact that most breeding programs are conducted under optimal $\mathrm{N}$ conditions and resulted in genotypes that not always perform well under low $\mathrm{N}$ input, and may have favored high-yielding genotypes with increased NUtE, but not those with a high NUpE. So there is a need to select for genotypes that are more efficient in $\mathrm{N}$ uptake and able to translocate larger amounts of $\mathrm{N}$ to grains without compromising on grain yield under limited $\mathrm{N}$.

Authors stress that the need to always include both aspects of NUE (NUpE and NUtE) as these aspects interact constantly during crop growth and development not only among each other but also in relation to soil $\mathrm{N}$ availability (Gastal and Lemaire 2002; Han et al. 2015). Wiesler et al. (2001) concluded from their research that for maize, high agronomic efficiency was achieved by combining high uptake and utilization efficiency but that for oilseed rape, the focus on high uptake efficiency also gave good results. Uribellarrea et al. (2007), who found that maize genotypes with high protein content excelled in NUpE and low protein genotypes in NUtE, suggested that crossing genotypes with contrasting protein contents could provide genetic variation to improve both $\mathrm{NUpE}$ and NUtE irrespective of the $\mathrm{N}$ level in the target environment.

There are not many papers quantifying the benefits of improving NUE. Bänzinger and Lafitte (1997) combined in maize several correlated traits as well as yield as selection criterion and were able to improve NUE by $14 \%$. Rathke et al. (2006) concluded from their research in winter oilseed rape production that by applying N-efficient management strategies, including choice of cultivar, form, and timing of $\mathrm{N}$ fertilization that are suitable for the prevailing growing conditions, a reduction up to $50 \%$ of fertilizer input could be achieved. Dresbøll and ThorupKristensen (2014) stressed that the effect of genotypes improved for NUE depends on the environment and the whole cropping system, and considered NUE as a resultant of $\mathrm{G} \times \mathrm{E} \times \mathrm{M}$. 
9.2 Do crop traits contributing to nitrogen use efficiency differ for different management strategies?

The sensitivity towards $\mathrm{G} \times \mathrm{E}$ interaction will also be complicated by different management strategies $(\mathrm{G} \times \mathrm{E} \times \mathrm{M})$. Applying different types of fertilization management (e.g., low or high $\mathrm{N}$ input, organic or conventional fertilizers) will not only require different agronomic management strategies to improve NUE (Thorup-Kristensen et al. 2012) but is also expected to require different genetic traits for high NUE in crops (e.g., Chan-Navarrete et al. 2014).

All discussed papers on research on perspectives to breed for NUE have been conducted under both low- and high-input growing conditions as the scope was generally to identify genotypes and traits that contribute to improving NUE without compromising on yield under low input. There is general agreement across crops on the fact that NUE increases when $\mathrm{N}$ is reduced (see, e.g., Hawkesford 2017). Nevertheless, breeding research often explicitly searches for those genotypes that perform well under low $\mathrm{N}$ and at the same time can potentially show good responsiveness to high $\mathrm{N}$ availability (e.g., Ospina et al. 2014; Han et al. 2015). There is a need to compare the performance of genotypes under various $\mathrm{N}$ levels as much research showed that those genotypes that perform well and are $\mathrm{N}$ efficient under high $\mathrm{N}$, are not always the same that are showing the highest NUE under low input; good performers under low $\mathrm{N}$ can be missed when selected under high $\mathrm{N}$ (Gallais and Coque 2005; Górny et al. 2011; ChanNavarrete et al. 2014; Ospina et al. 2014). Several researchers confirmed that there is clear indication that $\mathrm{N}$ fertilization levels have a critical influence on the $\mathrm{N}$ metabolisms and expression of gene actions governing $\mathrm{N}$ efficiency in wheat (Gallais and Coqie 2005; Górny et al. 2011). The large $\mathrm{G} \times \mathrm{N}$ interaction is because genotypes respond differently to $\mathrm{N}$ stress compared to conditions with luxurious $\mathrm{N}$ availability due to the fact that under $\mathrm{N}$ stress plants have different physiological mechanisms at their disposal to adjust to low $\mathrm{N}$ conditions (Gallais and Coque 2005; Górny et al. 2011). Many authors therefore recommend to select for NUE under the target environment for a high response to selection (e.g., Gallais and Coque 2005). Besides, under low N, often, genetic variation is best expressed to better select for NUE (TiemensHulscher et al. 2014).

Under organic management, not only the level of $\mathrm{N}$ is important but also the type of fertilizer affects the $\mathrm{N}$ dynamics in the soil (rate of release and availability of $\mathrm{N}$ for the plants). Organic sources of nitrogen (e.g., stable manure, compost) are often not abundant and nitrogen availability from organic resources is difficult to match precisely with the demand of the crop, especially under cold spring conditions as mineralization of $\mathrm{N}$ from organic fertilizers depends on soil micro-organism activity and soil temperature (Stockdale et al. 2002; Messmer et al. 2012). The majority of organic farms in Western Europe apply between 100 and $200 \mathrm{~kg} \mathrm{~N} \mathrm{ha}^{-1}$ per year in organic amendments. However, often, the $\mathrm{N}$ availability in the year of application is less than $100 \mathrm{~kg} \mathrm{~N}$ ha $^{-1}$ which leads to yield reduction of $\mathrm{N}$ demanding crops such as potato and cabbage (Finckh et al. 2006; Tiemens-Hulscher et al. 2014). Renaud et al. (2014) concluded from various trials comparing a set of 23 broccoli cultivars for their performance under conventional and organic conditions that overall the rankings of cultivars were similar (with exceptions) but that not all high-yielding genotypes were good performers with respect to yield stability across years and locations and were not very tolerant to $\mathrm{N}$ stress conditions, for example occurring in cold spring conditions.

Organic crop management is not only characterized by specific ways of nitrogen husbandry but also by disease management; the latter can also affect the NUE of cultivars. Under organic growing conditions with no fungicides and an early infestation of late blight that destroys the canopy of non-resistant cultivars, early cultivars of potato showed a higher NUE than (mid-)late cultivars (Tiemens-Hulscher et al. 2014) whereas under conventional conditions with crop protection, late cultivars showed a higher NUE than early and mid-early-maturing genotypes (Ospina et al. 2014). Kokare et al. (2017) showed for barley that selection for good adaptation to low-input organic farming conditions can be successfully conducted under conventional medium-input $\mathrm{N}$ fertilization levels rather than under high $\mathrm{N}$ levels under the condition that not only yield per se is considered as selection criterion but also yield stability and traits related to weed suppression as no herbicides are applied in organic farming systems (see also Dawson et al. 2008).

\subsection{Do crops differ in their genetic variability and prospects to improve nitrogen use efficiency and related traits?}

Most research papers for the analyzed crops indicated that there is sufficient genetic variation available among modern cultivars to select for and improve NUE components. Górny et al. (2011) concluded from their research with winter wheat that both old and modern wheat cultivars could serve as adequate initial donors of various efficiency components to combine them in segregating populations. Also, Dawson et al. (2011), in search for strategies to improve yield of wheat under low-input, organic farming conditions, came to the conclusion that one can benefit from using modern, productive varieties to improve NUE. This seems plausible as breeding has successfully focused on increasing yield by increasing harvest index mainly in grain crops, often leading to higher NUE.

However, with respect to below-ground traits (such as root length density and root biomass), there are reasons to surmise that useful variation might have been lost in modern plant 
breeding using optimal N supply in selection fields. See, e.g., Siddique et al. (1990) for wheat, Johnson et al. (2000) for lettuce, and De Melo (2003) for onion. Hawkesford (2017) showed in his review on NUE in modern wheat that under low $\mathrm{N}$, there is large variation in $\mathrm{N}$ uptake but little variation in yield, indicating that cultivars have little ability to convert the acquired $\mathrm{N}$ into yield. It is therefore expected that major improvements can be made in $\mathrm{N}$ acquisition and utilization when more diverse genotypes are screened to search for larger trait variation.

Our analysis showed that especially with the short-cycle crops, below-ground traits are very important but are more prone to $\mathrm{G} \times \mathrm{E}$ interactions than with long-cycle crops that have more time to compensate fluctuating growth conditions. It also showed that under field conditions, the impact of environmental variation was larger than that of the genotypic variation (Kerbiriou et al. 2016). Therefore, recommendations to identify effective selection traits point in different directions. One option is to develop a controlled system for (early) selection such as a hydroponic system eliminating environmental variation affecting expression of traits related to NUE (ChanNavarrete et al. 2014). However, the final selection always needs to be done under field conditions. Another option is to develop more in-depth analysis of the physiological mechanisms at root level allowing sustained shoot growth. An ecophysiological model can assist breeders in their selection process as it is capable of reducing the residual variance and improving the expression and evaluation of cultivar differences in relation to $\mathrm{N}$ uptake and use efficiency (Hirel et al. 2011; Kerbiriou et al. 2014; Gu et al. 2014). In addition, Han et al. (2015) stressed the relative importance of accurate phenotyping and experimental designs over genotyping for such complex traits as NUE.

\section{Conclusions}

From our analysis, we conclude that knowledge gained on improving NUE in one crop species cannot be easily transferred to another crop species. Short-cycle crops respond differently from long-cycle crops, and vegetative crops differ in their N management from grain-producing crops. Despite extensive research on NUE in large crops such as wheat, oilseed rape, and maize, many significant correlations between belowand above-ground traits and $\mathrm{N}$ levels are physiologically not yet well understood and call for more research including research on other factors influencing the uptake process such as root exudates, available rhizobium, or nitrate transport systems. The complexity of improving NUE requires integration of agronomy, breeding, and crop physiology to better understand the interactions of the NUE components and their related traits with various environmental conditions.
Open Access This article is distributed under the terms of the Creative Commons Attribution 4.0 International License (http:// creativecommons.org/licenses/by/4.0/), which permits unrestricted use, distribution, and reproduction in any medium, provided you give appropriate credit to the original author(s) and the source, provide a link to the Creative Commons license, and indicate if changes were made.

\section{References}

Andresen M, Dresbøll DB, Stoumann Jensen L, Magid J, ThorupKristensen K (2016) Cultivar differences in spatial root distribution during early growth in soil, and its relation to nutrient uptake-a study of wheat, onion and lettuce. Plant Soil 408:255-270. https:// doi.org/10.1007/s11104-016-2932-Z

Baan Hofman T (1988) Effecten van stikstof en maaifrequentie op de drogestofopbrengst van Engels raaigrasrassen die verschillen in persistentie, Report No 86, Centrum voor Agro-biologisch Onderzoek (CABO), Wageningen, pp 27

Balint T, Rengel Z (2008) Nitrogen efficiency of canola genotypes varies between vegetative stage and grain maturity. Euphytica 164(2):421432. https://doi.org/10.1007/s10681-008-9693-6

Bänziger M, Lafitte HR (1997) Efficiency of secondary traits for improving maize for low nitrogen target environments. Crop Sci 37:1110-1117. https://doi.org/10.2135/cropsci1997.0011183X003700040013x

Baresel JP, Zimmermann G, Reents HJ (2008) Effects of genotype and environment on $\mathrm{N}$ uptake and $\mathrm{N}$ partition in organically grown winter wheat (Triticum aestivum L.) in Germany. Euphytica 163:347354. https://doi.org/10.1007/s10681-008-9718-1

Barraclough PB (1989) Root growth, macro-nutrient uptake dynamics and soil fertility requirements of a high-yielding winter oilseed rape crop. Plant Soil 119:59-70. https://doi.org/10.2489/jswc.70.6.399

Barraclough PB, Howarth JR, Jones J, Lopez-Bellido R, Parmar S, Shepherd CE, Hawkesford MJ (2010) Nitrogen efficiency of wheat: genotypic and environmental variation and prospects for improvement. Eur J Agron 33:1-11. https://doi.org/10.1016/j.eja.2010.01.005

Berry PM, Spink J, Foulkes MJ, White PJ (2010) The physiological basis of genotypic differences in nitrogen use efficiency in oilseed rape (Brassica napus L.) Field Crops Res 119(2-3):365-373. https://doi. org/10.1016/j.fcr.2010.08.004

Biemond H (1995) Effects of nitrogen on development and growth of the leaves of vegetables. 3. Appearance and expansion growth of leaves of spinach. Neth J Ag Sci 43:247-260

Bottoms TG, Smith RF, Cahn MD, Hartz TK (2012) Nitrogen requirements and $\mathrm{N}$ status determination of lettuce. Hortscience 47:17681774. https://doi.org/10.1080/01448765.2014

Burns IG, Hammond JP, White PJ (2010) Precision placement of fertiliser for optimising the early nutrition of vegetable crops: a review of the implications for the yield and quality of crops, and their nutrient use efficiency. Acta Hortic 852:177-188 http://www.actahort.org/ books/852/852 21.htm

Caihong C, Chenliu L (1989) Studies on the characters of nitrogen nutrition of high yielding hybrid rice Shan-You 63. Huaz Hong Agricultural University 1:1-9

CBAV (2016) Handboek Bodem en bemesting. Commissie Bemesting Akkerbouw/Vollegrondsgroenten. Lelystad, The Netherlands. Available at: http://www.handboekbodemenbemesting.nl/nl/ handboekbodemenbemesting/Handeling/Bemesting/Stikstof/ Vollegrondsgroenten.htm. Accessed 5 Mar 2017

CDFA (2017) California fertilisation guidelines. Available at: https:// apps1.cdfa.ca.gov/fertilizerresearch/docs/guidelines.html. Accessed 5 Mar 2017

Chan-Navarrete R, Kawai A, Dolstra O, Lammerts van Bueren ET, Van der Linden CG (2014) Genetic diversity of nitrogen use efficiency in 
spinach (Spinacia oleracea L.) cultivars using the Ingestad model on hydroponics. Euphytica 199(1-2):155-166. https://doi.org/10.1007/ s10681-014-1186-1

Chan-Navarrete R, Dolstra O, Van Kaauwen M, Lammerts van Bueren ET, Van der Linden CG (2016) Genetic map construction and QTL analysis of nitrogen use efficiency in spinach (Spinacia oleracea L.) Euphytica 208(3):621-636. https://doi.org/10.1007/s10681-015-1618-6

Chen K, Camberato JJ, Tuinstra MR, Kumudini SV, Tollenaar M, Vyn TJ (2016) Genetic improvement in density and nitrogen stress tolerance traits over 38 years of commercial maize hybrid release. Field Crops Res 196:438-451. https://doi.org/10.1016/j.fcr.2016.07.025

Ciampitti IA, Vyn TJ (2011) A comprehensive study of plant density consequences on nitrogen uptake dynamics of maize plants from vegetative to reproductive stages. Field Crops Res 121:2-18. https://doi.org/10.1016/j.fcr.2010.10.009

Ciampitti IA, Vyn TJ (2012) Physiological perspectives of changes over time in maize yield dependency on nitrogen uptake and associated nitrogen efficiencies: a review. Field Crops Res 133:48-67. https:// doi.org/10.1016/j.fcr.2012.03.008

Ciampitti IA, Vyn TJ (2013) Grain nitrogen source changes over time in maize: a review. Crop Sci 53(2):366-377. https://doi.org/10.2135/ cropsci2012.07.0439

Coque M, Gallais A (2007) Genetic variation among European maize varieties for nitrogen use efficiency under low and high nitrogen fertilization. Maydica 52:383-397

Craswell ET, Godwin DC (1984)The efficiency of nitrogen fertilizers applied to cereals in different climates. In: Tinker PB, Lauchli A (eds) Advances in Plant nutrition, vol 1. Praeger Publishers, New York, pp 1-55

Craswell ET, Lefroy RDB (2001) The role and function of organic matter in tropical soils. Nutr Cycl Agroecosys 61(1):7-18. https://doi.org/ 10.1023/A:1013656024633

Darwinkel A (1978) Patterns of tillering and grain production of winter wheat at a wide range of plant densities. Neth J Agr Sci 26:383-398

Dawson JC, Huggins DR, Jones SS (2008) Characterizing nitrogen use efficiency in natural and agricultural ecosystems to improve the performance of cereal crops in low-input and organic agricultural systems. Field Crops Res 107(2):89-101. https://doi.org/10.1016/j. fcr.2008.01.001

Dawson JC, Murphy KM, Huggins DR, Jones SS (2011) Evaluation of winter wheat breeding lines for traits related to nitrogen use under organic management. Org Agr 1:65-80. https://doi.org/10.1007/ s13165-011-0006-3

De Koeijer TJ, Wossink GAA, Van Ittersum MK, Struik PC, Renkema JA (1999) A conceptual model for analysing input-output coefficients in arable farming systems: from diagnosis towards design. Agr Sys 61:33-44. https://doi.org/10. 1016/j.jenvman.2008.11.014

De Melo PE (2003). The root systems of onion and Allium fistulosum in the context of organic farming: a breeding approach. PhD Thesis, Wageningen Agricultural University, The Netherlands. 136 pp. http://edepot.wur.nl/121472

De Wit CT (1992) Resource use efficiency in agriculture. Agr Sys 40: 125-151

Diepenbrock W (2000) Yield analysis of winter oilseed rape (Brassica napus L.): a review. Field Crops Res 67(1:35-49. https://doi.org/10. 1016/S0378-4290(00)00082-4

Dreccer MF, Schapendonk AHCM, Slafer GA, Rabbinge R (2000) Comparative response of wheat and oilseed rape to nitrogen supply: absorption and utilisation efficiency of radiation and nitrogen during the reproductive stages determining yield. Plant Soil 220:189-205

Dresbøll DB, Thorup-Kristensen K (2014) Will breeding for nitrogen use efficient crops lead to nitrogen use efficient cropping systems?: a simulation study of $\mathrm{G} \times \mathrm{E} \times \mathrm{M}$ interactions. Euphytica 199:97-117. https://doi.org/10.1007/s10681-014-1199-9
Ehdaie B, Merhaut DJ, Ahmadian S, Hoops AC, Khuong T, Layne AP, Waines JG (2010) Root system size influences water-nutrient uptake and nitrate leaching potential in wheat. J Agron Crop Sci 196:455466. https://doi.org/10.1111/j.1439-037X.2010.00433.x

Erisman JW, Galloway JA, Sutton MS, Klimont Z, Winiwater W (2008) How a century of ammonia synthesis changed the world. Nat Geosci 1:636-639. https://doi.org/10.1038/ngeo325

Evans JR, Poorter H (2001) Photosynthetic acclimation of plants to growth irradiance: the relative importance of specific leaf area and nitrogen partitioning in maximizing carbon gain. Plant Cell Environ 24:755-767. https://doi.org/10.1046/j.1365-3040.2001.00724.x

Everaarts AP (1993) General and quantitative aspects of nitrogen fertiliser use in the cultivation of Brassica vegetables. Acta Hortic 339:149-160

Everaarts AP, Booij R (2000) The effect of nitrogen application on nitrogen utilization by white cabbage (Brassica oleracea var. capitata) and on nitrogen in the soil at harvest. J Hortic Sci Biotechnol 75: 705-712. https://doi.org/10.1080/14620316.2000.11511311

Finckh MR, Schulte-Geldermann E, Bruns C (2006) Challenges to organic potato farming: disease and nutrient management. Potato Res 49:27-42. https://doi.org/10.1007/s11540-006-9004-3

Foulkes MJ, Hawkesford MJ, Barraclough PB, Holdsworth MJ, Kerr S, Kightley S, Shewry PR (2009) Identifying traits to improve the nitrogen economy of wheat: recent advances and future prospects. Field Crops Res 114:329-342. https://doi.org/10.1016/j.fcr.2009.09.005

Gaju O, Allard V, Martre P, Snape JW, Heumez E, Le Gouis J, Bogard M, Griffiths S, Orford S, Hubbart S, Foulkes MJ (2011) Identification of traits to improve the nitrogen-use efficiency of wheat genotypes. Field Crops Res 123:139-152. https://doi.org/10.1016/j.fcr.2011.05.010

Gaju O, Allard V, Martre P, Le Gouis J, Moreau D, Bogard M, Hubbart S, Foulkes MJ (2014) Nitrogen partitioning and remobilization in relation to leaf senescence, grain yield and grain nitrogen concentration in wheat cultivars. Field Crops Res 155:213-223. https://doi. org/10.1016/j.fcr.2013.09.003

Gallais A, Coque M (2005) Genetic variation and selection for nitrogen use efficiency in maize: a synthesis. Maydica 50:531-547

Galván GA, Kuyper TW, Burger K, Keizer LCP, Hoekstra RF, Kik C, Scholten OE (2011) Genetic analysis of the interaction between Allium species and arbuscular mycorrhizal fungi. Theor Appl Gen 122:947-960. https://doi.org/10.1007/s00122-010-1501-8

Gastal F, Lemaire G (2002) N uptake and distribution in crops: an agronomical and ecophysiological perspective. J Exp Bot 53(370): 789-799. https://doi.org/10.1093/jexbot/53.370.789

Geiger HH (2009) Agronomic traits and maize modifications: nitrogen use efficiency. In: Bennetzen JL, Hake SC (eds) Handbook of maize: its biology. Springer Science, New York, pp 405-417

Gewin V (2010) Food: an underground revolution. Nature 466:553. https://doi.org/10.1038/466552a

Good AG, Shrawat AK, Muench DG (2004) Can less yield more? Is reducing nutrient input into the environment compatible with maintaining crop production? Trends Plant Sci 9(12):597-605. https:// doi.org/10.1016/j.tplants.2004.10.008

Górny AG, Banaszak Z, Ługowska B, Ratajczak D (2011) Inheritance of the efficiency of nitrogen uptake and utilization in winter wheat (Triticum aestivum L.) under diverse nutrition levels. Euphytica 177:191-206. https://doi.org/10.1007/s10681-010-0230-z

Goulding K, Jarvis S, Whitmore A (2008) Optimizing nutrient management for farm systems. Phil Trans R Soc B 363:667-680. https://doi. org/10.1098/rstb.2007.2177

Greenwood DJ, Draycott A (1988) Quantitative relationships for growth and $\mathrm{N}$ content of different vegetable crops grown with and without ample fertilizer-N on the same soil. Fertilizer Res 18:175-188. https://doi.org/10.1007/BF01049512

Gu J, Yin X, Zhang C, Wang H, Struik PC (2014) Linking ecophysiological modelling with quantitative genetics to support marker-assisted crop design for improved yields of rice 
(Oryza sativa) under drought stress. Ann Bot 114:499-511. https://doi.org/10.1093/aob/mcu127

Han M, Okamoto M, Beatty PH, Rothstein RJ, Good AG (2015) The genetics of nitrogen use efficiency in crop plants. Annu Rev Genet 49:269-289. https://doi.org/10.1146/annurev-genet-112414-055037

Harrier LA (2001) The arbuscular mycorrhizal symbiosis: a molecular review of the fungal dimension. J Exp Bot 52:469-478

Hartemink AE, Johnston M, O'Sullivan JN, Poloma S (2000) Nitrogen use efficiency of taro and sweet potato in the humid lowlands of Papua New Guinea. Agric Ecosyst Environ 79:271-280

Hartman Y, Hooftman DAP, Uwimana B, Schranz ME, Van der Wiel CCM, Smulders MJM, Visser RGF, Van Tienderen PH (2014) Abiotic stress QTL in lettuce crop-wild hybrids: comparing greenhouse and field experiments. Ecol Evol 4(12):2395-2409. https:// doi.org/10.1002/ece3.1060

Hartz TK, Bendixen WE, Wierdsma L (2000) The value of pre-side dress soil nitrate testing as a nitrogen management tool in irrigated vegetable production. Hortscience 35:651-656

Hawkesford MJ (2017) Genetic variation in traits for nitrogen use efficiency in wheat. J Exp Bot 68(10):2627-2632. https://doi.org/10. 1093/jxb/erx079

Hirel B, Bertin P, Quilleré I, Bourdoncle W, Attagnant C, Dellay C, Gouy A, Cadiou S, Retailliau C, Falque M, Gallais A (2001) Towards a better understanding of the genetic and physiological basis for nitrogen use efficiency in maize. Plant Physiol 125(3):1258-1270. https://doi.org/10.1104/pp.125.3.1258

Hirel B, Tétu T, Lea PJ, Dubois F (2011) Improving nitrogen use efficiency in crops for sustainable agriculture. Sustainability $3: 1452$ 1485. https://doi.org/10.3390/su3091452

Hodge A (2004) The plastic plant: root responses to heterogeneous supplies of nutrients. New Phytol 162:9-24. https://doi.org/10.1111/j. 1469-8137.2004.01015.x

Iwama K (2008) Physiology of the potato: new insights into root system and repercussions. Potato Res 51:333-353. https://doi.org/10.1007/ s11540-008-9120-3

Johnson WC, Jackson LE, Ochoa O, Van Wijk R, Peleman J, St.Clair DA, Michelmore RW (2000) Lettuce, a shallow rooted crop, and Lactuca serriola, its wild progenitor, differ at QTL determining root architecture and deep soil water exploitation. Theor Appl Genet 101:10661073. https://doi.org/10.1007/s001220051581

Kerbiriou P, Lammerts van Bueren ET, Stomph TJ, Struik PC (2013a) Shoot growth, root growth and resource capture under limiting growing conditions for two cultivars of lettuce (Lactuca sativa L.) Plant Soil 371:281-297. https://doi.org/ 10.1007/s11104-013-1672-6

Kerbiriou P, Stomph TJ, Lammerts van Bueren ET, Struik PC (2013b) Influence of transplant size on the above- and below-ground performance of four contrasting field-grown lettuce cultivars. Front Plant Sci 4:379, 16 pp. https://doi.org/10.3389/fpls.2013.00379

Kerbiriou PJ, Stomph TJ, Lammerts van Bueren ET, Struik PC (2014) Modelling concept of lettuce breeding for nutrient efficiency. Euphytica 199(1-2):167-188. https://doi.org/10.1007/s10681-0141198-x

Kerbiriou PJ, Maliepaard CA, Stomph TJ, Koper M, Froissart D, Roobeek I, Lammerts van Bueren ET, Struik PC (2016) Genetic control of water and nitrate capture and their use efficiency in lettuce (Lactuca sativa L.) Front Plant Sci 7:343, 14 pp. https://doi.org/10. 3389/fpls.2016.00343

Kessel B, Schierholt A, Becker HC (2012) Nitrogen use efficiency in a genetically diverse set of winter oilseed rape (Brassica napus L.) Crop Sci 52:2546-2554. https://doi.org/10.2135/cropsci2012.02.0134

Kichey T, Hirel B, Heumez E, Dubois F, Le Gouis J (2007) In winter wheat (Triticum aestivum L.), post-anthesis nitrogen uptake and remobilisation to the grain correlate with agronomic traits and nitrogen physiological markers. Field Crops Res 102:22-32. https://doi. org/10.1016/j.fcr.2007.01.002
Koike S, Cahn M, Cantwell M, Fennimore S, LeStrange M, Natwick E, Smith RF, Takele E (2011) Spinach production in California. Oakland: University of California. ANR publication 7212. http:// anrcatalog.ucdavis.edu/pdf/7212.pdf

Kokare A, Legzdina L, Maliepaard C, Niks RE, Lammerts van Bueren ET (2017) Comparison of selection efficiency for spring barley (Hordeum vulgare L.) under organic and conventional farming conditions. Crop Sci 57(2):626-636. https://doi.org/10.2135/ cropsci2015.11.0691

Kramer AW, Doane TA, Horwath WR, Van Kessel C (2002) Combining fertilizer and organic inputs to synchronize $\mathrm{N}$ supply in alternative cropping systems in California. Agric Ecosyst Environ 91:233-243. https://doi.org/10.1016/S0167-8809(01)00226-2

Kristensen HL, Thorup-Kristensen K (2004) Root growth and nitrate uptake of three different catch crops in deep soil layers. Soil Sci Soc Am J 68:529-537. https://doi.org/10.2136/sssaj2004.0529

Labra MH, Struik PC, Evers JB, Calderini DF (2017) Plasticity of seed weight compensates reductions in seed number of oilseed rape in response to shading at flowering. Eur J Agron 84:113-124. https:// doi.org/10.1016/j.eja.2016.12.011

Lauer DA (1985) Nitrogen uptake patterns of potatoes with highfrequency sprinkler-applied N fertilizer. Agron J 77:193-197

Le Gouis J, Béghin D, Heumex E, Pluchard P (2000) Genetic differences for nitrogen uptake and use efficiency in winter wheat. Eur J Agron 12:163-173. https://doi.org/10.1016/S1161-0301(00)00045-9

Linquist BA, Cassman KG, Fulton AE, Jackson LF (1992) Late-season nitrogen may be efficient way to increase winter wheat protein. Calif Agr 46(2): 13-16

Malagoli P, Laine P, Rossato L, Ourry A (2005) Dynamics of nitrogen uptake and mobilization in field-grown winter oilseed rape (Brassica napus) from stem extension to harvest- $\mathrm{I}$. Global $\mathrm{N}$ flows between vegetative and reproductive tissues in relation to leaf fall and their residual N. Ann Bot 95:853-861. https://doi.org/10.1093/aob/mci091

Masclaux-Daubresse C, Daniel-Vedele F, Dechorgnat J, Chardon F, Gaufichon L, Suzuki A (2010) Nitrogen uptake, assimilation and remobilization in plants: challenges for sustainable and productive agriculture. Ann Bot 105:1141-1157. https://doi.org/10.1093/aob/mcq028

Maydup ML, Anotnietta M, Guiamet JJ, Graciano C, López JR, Tambussi EA (2010) The contribution of ear photosynthesis to grain filling in bread wheat (Triticum aestivum L.) Field Crops Res 119: 48-58. https://doi.org/10.1016/j.fcr.2010.06.014

Messmer M, Hildermann I, Thorup-Kristensen K, Rengel Z (2012) Nutrient management in organic farming and consequences for direct and indirect selection strategies. In: Lammerts van Bueren ET, Myers JR (eds) Organic crop breeding. Wiley-Blackwell, Hoboken, pp 15-35

Mirsky SB, Ryan MR, Curran WS, Teasdale JR, Maul J, Spargo JT, Moyer J, Grantham AM, Weber D, Way TR, Camargo GG (2012) Conservation tillage issues: cover crop-based organic rotational notill grain production in the mid-Atlantic region, USA. Ren Agr Food Syst 27:31-40. https://doi.org/10.1017/S1742170511000457

Moll RH, Kamprath EJ, Jackson WA (1982) Analysis and interpretation of factors which contribute to efficiency of nitrogen utilization. Agron J 74:562-564

Morgan CL, Ladbrooke Z, Arthur AE, Bruce D, Child R (1998) Variation for pod shatter resistance in B. napus. Acta Hortic 459(49):411-418

Neeteson JJ, Wadman WP (1987) Assessment of economically optimum application rates of fertilizer $\mathrm{N}$ on the basis of response curves. Fertil Res 12:37-52

Nyikako J, Schierholt A, Kessel B, Becker HC (2014) Genetic variation in nitrogen uptake and utilization efficiency in a segregating $\mathrm{DH}$ population of winter oilseed rape. Euphytica 199:3-11. https://doi. org/10.1007/s10681-014-1201-6

Ortiz-Monasterio RJI, Sayre KD, Rajaram S, McMahon M (1997) Genetic progress in wheat yield and nitrogen use efficiency under four nitrogen rates. Crop Sci 37(3):898-904 
Osman AM, Struik PC, Lammerts van Bueren ET (2012) Perspectives to breed for improved baking quality for wheat varieties adapted to organic growing conditions. J Sci Food Agri 92:207-215. https:// doi.org/10.1002/jsfa.4710

Ospina Nieto CA (2016) Nitrogen use efficiency in potato: an integrated agronomic, physiological and genetic approach. PhD thesis Wageningen University, Wageningen, The Netherlands. http:// edepot.wur.nl/378131. Accessed 28 Mar 2017

Ospina CA, Lammerts van Bueren ET, Allefs JJHM, Engel B, van der Putten PEL, van der Linden CG, Struik PC (2014) Diversity of crop development traits and nitrogen use efficiency among potato cultivars grown under contrasting nitrogen regimes. Euphytica 199(1-2): 13-29. https://doi.org/10.1007/s10681-014-1203-4

Penning de Vries FWT, van Keulen H (1982) La production actuelle et l'action de l'azote et du phosphore. In: Penning de Vries FWT, Djiteye MA (Eds) La productivité des paturages saheliens: une étude des sols, des vegetations et de l'exploitation de cette ressource naturelle, Agr Res Rep 918, Pudoc, Wageningen, pp 165-181

Pestsova E, Lichtblau D, Wever C, Presterl T, Bolduan T, Ouzunova M, Westhoff P (2016) QTL mapping of seedling root traits associated with nitrogen and water use efficiency in maize. Euphytica 209: 585-602. https://doi.org/10.1007/s10681-015-1625-7

Philippot L, Raaijmakers JM, Lemanceau P, Van der Putten WH (2013) Going back to the roots: the microbial ecology of the rhizosphere. Nat Rev Microbiol 11:789-799. https://doi.org/10.1038/ nrmicro3109

Presterl T, Groh S, Landbeck M, Seitz G, Schmidt W, Geiger HH (2002) Nitrogen uptake and utilization efficiency of European maize hybrids developed under conditions of low and high nitrogen input. Plant Breed 121(6):480-486. https://doi.org/10.1046/j.1439-0523. 2002.00770.x

Racjan I, Tollenaar M (1999) Source:sink ratio and leaf senescence in maize: I. Dry matter accumulation and partitioning during grain filling. Field Crops Res 60:245-253

Rather E, Schenk MK, Everaarts AP, Vethman S (2000) Rooting patterns and nitrogen uptake of three cauliflowers (Brassica oleracea var. botrytis) $\mathrm{F}_{1}$-hybrids. J Plant Nutr Soil Sci 163:467-474

Rathke G-W, Behrens T, Diepenbrock W (2006) Integrated nitrogen management strategies to improve seed yield, oil content and nitrogen efficiency of winter oilseed rape (Brassica napus L.): a review. Agric Ecosyst Environ 117:80-108. https://doi.org/10.1016/j.agee. 2006.04.006

Renaud ENC, Lammerts van Bueren ET, Paulo MJ, van Eeuwijk FA, Juvik JA, Hutton MG, Myers JR (2014) Broccoli cultivar performance under organic and conventional management systems and implications for crop improvement. Crop Sci 54(4):1539-1554. https://doi.org/10.2135/cropsci2013.09.0596

Ritchie SW, Hanway JJ, Benson GO (1993) How a corn plant develops. Special report number 48. Iowa State University of Science and Technology, Ames

Robertson GP, Vitousek PM (2009) Nitrogen in agriculture: balancing the cost of an essential resource. Annu Rev Environ Resour 34:97-125. https://doi.org/10.1146/annurev.environ.032108.105046

Robinson D (1994) The responses of plants to non-uniform supplies of nutrients. New Phytol 127:635-674

Sanchez-Bragado R, Molero G, Reynolds MP, Araus JL (2016) Photosynthetic contribution of the ear to grain filling in wheat: a comparison of different methodologies for evaluation. J Exp Bot 67(9):2787-2798. https://doi.org/10.1093/jxb/erw116

Sattelmacher B, Klotz F, Marschner H (1990) Influence of the nitrogen level on root growth and morphology of two potato varieties differing in nitrogen acquisition. Plant Soil 123(2):131-137. https://doi. org/10.1007/BF00011258

Sattelmacher B, Horst WJ, Becker HC (1994) Factors that contribute to genetic variation for nutrient efficiency of crop plants. Z Pflanzenernähr Bodenk 157:215-224
Schenk M, Heins B, Steingrobe B (1991) The significance of root development of spinach and kohlrabi for N fertilization. Plant Soil 135(2): 197-203

Schjoerring JK, Bock JGH, Gammelvind L, Jensen CR, Mogensen VO (1995) Nitrogen incorporation and remobilization in different shoot components of field-grown winter oilseed rape (Brassica napus L.) as affected by rate of nitrogen application and irrigation. Plant Soil 177:255-264

Schröder JJ (2014) The position of mineral nitrogen fertilizer in efficient use of nitrogen and land: a review. Nat Resour J 5(15):936-948. https://doi.org/10.4236/nr.2014.515080

Schulte auf'm Erley G, Wijaya K-A, Ulas A, Becker H, Wiesler F, Horst WJ (2007) Leaf senescence and N uptake parameters as selection traits for nitrogen efficiency of oilseed rape cultivars. Physiol Plant 130:519-531. https://doi.org/10.1111/j.1399-3054

Schulte auf'm Erley G, Dewi R, Nikus O, Horst WJ (2010) Genotypic differences in nitrogen efficiency of white cabbage (Brassica oleracea L.) Plant Soil 328:313-325. https://doi.org/10.1007/ s11104-009-0111-1

Schulte auf'm Erley G, Behrens T, Ulas A, Wiesler F, Horst WJ (2011) Agronomic traits contributing to nitrogen efficiency of winter oilseed rape. Field Crops Res 124:114-123. https://doi.org/10.1016/j. fcr.2011.06.009

Sibley KJ, Astatkie T, Brewster G, Struik PC, Adsett JF, Pruski K (2009) Field-scale validation of an automated soil nitrate extraction and measurement system. Precis Agric 10:162-174. https://doi.org/10. 1007/s11119-008-9081-1

Sibley KJ, Brewster GR, Astatkie T, Adsett JF, Struik PC (2010) In-field measurement of soil nitrate using an ion-selective electrode. In: Milind $\mathrm{Kr}$ Sharma (Ed.), Advances in measurement systems. ISBN: 978-953-307-061-2, InTech. Available from: http://www. intechopen.com/books/advances-in-measurement-systems/infieldmeasurement-of-soil-nitrate-using-an-ion-selective-electrode. Accessed 26 Jan 2017

Siddique KHM, Belford RK, Tennant D (1990) Root-shoot ratios of old and modern, tall and semi-dwarf wheats in a Mediterranean environment. Plant Soil 121:89-98. https://doi.org/10.1016/j.ecolecon. 2012.01.022

Sinclair TR, De Wit CT (1975) Photosynthate and nitrogen requirements for seed production by various crops. Science 189(4202):565-567. https://doi.org/10.1126/science.189.4202.565

Spiertz JHJ (1980) Grain production of wheat in relation to nitrogen, weather and diseases. In: Hurd RG, Dennis C (eds) Increasing opportunities for crop yields. Pitman, Boston, pp 97-113

Spiertz JHJ (2010) Nitrogen, sustainable agriculture and food security: a review. Agron Sustain Dev 30:43-55. https://doi.org/10.1051/agro: 2008064

Spiertz JHJ, Ellen J (1978) Effects of nitrogen on crop development and grain growth of winter wheat in relation to assimilation and utilization of assimilates and nutrients. Neth J Agric Sci 26:201-231

Stockdale EA, Shepherd MA, Fortune S, Cuttle SP (2002) Soil fertility in organic farming systems - fundamentally different? Soil Use Manag 18(1):301-308. https://doi.org/10.1079/SUM2002143

Swain EY, Rempelos L, Orr CH, Hall G, Chapman R, Almadni M, Stockdale EA, Kidd J, Leifert C, Cooper JM (2014) Optimizing nitrogen use efficiency in wheat and potatoes: interactions between genotypes and agronomic practices. Euphytica 199:119-136. https://doi.org/10.1007/s10681-014-1181-6

Thompson TL, Doerge TA (1996) Nitrogen and water interactions in subsurface trickle irrigated leaf lettuce II. Agronomic, economic, and environmental outcomes. Soil Sci Soc Am J 60:168-173

Thorup-Kristensen K (2006a) Root growth and nitrogen uptake of carrot, early cabbage, onion and lettuce following a range of green manures. Soil Use Manag 22:29-38. https://doi.org/10.1111/j.14752743.2005.00012.x 
Thorup-Kristensen K (2006b) Effect of deep and shallow root systems on the dynamics of soil inorganic $\mathrm{N}$ during 3-year crop rotations. Plant Soil 288:233-248. https://doi.org/10.1007/s11104-006-9110-7

Thorup-Kristensen K, Nygaard Sørensen J (1999) Soil nitrogen depletion by vegetable crops with variable root growth. Acta Agr Scand, Section B - Soil \& Plant Science 49(2):92-97

Thorup-Kristensen K, Van den Boogaard R (1998) Temporal and spatial root development of cauliflower (Brassica oleracea L. var. botrytis L.) Plant Soil 201:37-47

Thorup-Kristensen K, Salmerón Cortasa M, Loges R (2009) Winter wheat roots grow twice as deep as spring wheat roots, is this important for N uptake and N leaching losses? Plant Soil 322:101-114. https://doi.org/10.1007/s11104-009-9898-Z

Thorup-Kristensen K, Dresbøll DB, Kristensen HL (2012) Crop yield, root growth, and nutrient dynamics in a conventional and three organic cropping systems with different levels of external inputs and $\mathrm{N}$ re-cycling through fertility building crops. Eur J Agron 37: 66-82. https://doi.org/10.1016/j.eja.2011.11.004

Tiemens-Hulscher M, Lammerts van Bueren ET, Struik PC (2014) Identifying nitrogen efficient potato cultivars for organic farming. Euphytica 199(1-2):137-154. https://doi.org/10.1007/s10681-014$1143-\mathrm{Z}$

Tilman D, Cassman KG, Matson PA, Naylor R, Polasky S (2002) Agricultural sustainability and intensive production practices. Nature 418(6898):671-677. https://doi.org/10.1038/nature01014

Tollenaar M, Lee E (2011) 2 strategies for enhancing grain yield in maize. Plant Breeding Rev 34:37-82. https://doi.org/10.1002/ 9780470880579.ch2

Trachsel S, Kaeppler SM, Brown KM, Lynch JP (2013) Maize root growth angles become steeper under low $\mathrm{N}$ conditions. Field Crops Res 140:18-31. https://doi.org/10.1016/j.fcr.2012.09.010

Tremblay N, Bélec C (2006) Adapting nitrogen fertilization to unpredictable seasonal conditions with least impact on the environment. HortTechnology 16(3):408-412
Uribelarrea M, Moose SP, Below FE (2007) Divergent selection for grain protein affects nitrogen use in maize hybrids. Field Crops Res 100: 82-90. https://doi.org/10.1016/j.fcr.2006.05.008

Van Alphen BJ, Stoorvogel JJ (2000) A methodology for precision nitrogen fertilization in high-input farming systems. Precis Agric 2(4): 319-332. https://doi.org/10.1023/A:1012338414284

Van Keulen H (1982) Graphical analyses of annual crop response to fertiliser application. Agric Syst 9:113-126

Van Keulen H, Seligman NG (1987) Simulation of water use, nitrogen nutrition and growth of a spring wheat crop. Simulation monographs. Pudoc, Wageningen

Vos J (1997) The nitrogen response of potato (Solanum tuberosum L.) in the field: nitrogen uptake and yield, harvest index and nitrogen concentration. Potato Res 40:237-248. https://doi.org/10.1007/ BF02358249

Vos J (1999) Split nitrogen application in potato: effects on accumulation of nitrogen and dry matter in the crop and on the soil nitrogen budget. J Agric Sci Camb 133:263-274

Vos J (2009) Nitrogen responses and nitrogen management in potato. Potato Res 52:305-317. https://doi.org/10.1007/s11540-009-9145-2

Wiesler F, Behrens T, Horst WJ (2001) The role of nitrogen-efficient cultivars in sustainable agriculture. Sci World 1(S2):61-69. https:// doi.org/10.1100/tsw.2001.264

Wilson R, Culp D, Nicholson K (2012) Classic Russet and Russet Norkotah potato yield and quality response to nitrogen fertilization. UC ANR Research Report \#151

Zebarth BJ, Tai G, Tarn R, De Jong H, Milburn PH (2004) Nitrogen use efficiency characteristics of commercial potato cultivars. Can J Plant Sci 84(2):589-598. https://doi.org/10.4141/P03-050 